\title{
Biofertigation of Forage With Effluents of Green Line of a Cattle Slaughterhouse: Microbial Diversity and Leaf Dry Mass Productivity
}

\author{
Joaquim Jose de Carvalho ${ }^{1}$, José Maria Rodrigues da Luz ${ }^{2}$, Jaqueline Henrique ${ }^{3}$, José Geraldo Delvaux Silva ${ }^{4}$, \\ José Expedito Cavalcante da Silva ${ }^{5} \&$ Edivaldo Alves dos Santos ${ }^{6}$ \\ 1 Doutorando em Biotecnologia e Biodiversidade do Programa de Pós-Graduação da Rede Bionorte, \\ Universidade Federal do Tocantins, Palmas, TO, Brazil \\ ${ }^{2}$ Pós-doutor of Programa de Pós-graduação em Solo e Nutrição de planta do Departamento de Solos da \\ Universidade Federal de Viçosa, MG, Brazil \\ 3 Doutoranda em Biotecnologia e Biodiversidade do Programa de Pós-Graduação da Rede Bionorte, \\ Universidade Federal do Tocantins, Palmas, TO, Brazil \\ ${ }^{4}$ Professor Doutor do CEULP/ULBRA, TO, Brazil \\ ${ }^{5}$ Professor Doutor da Universidade Federal do Tocantins, TO, Brazil \\ ${ }^{6}$ Professor Mestre do Instituto Federal do Tocantins, TO, Brazil \\ Correspondence: José Expedito Cavalcante da Silva, Universidade Federal do Tocantins, TO, Brazil. Tel: \\ 55-063-3232-8007. E-mail: jecs@mail.uft.edu.br
}

Received: January 12, 2018

Accepted: April 6, $2018 \quad$ Online Published: April 15, 2018

doi:10.5539/jas.v10n5p353

URL: https://doi.org/10.5539/jas.v10n5p353

\begin{abstract}
The wastewater has been an environmental problem, but your used as fertilizers could reduce or eliminate the application of commercial fertilizers in soil. Arbuscular mycorrhizal fungi (AMF) and nitrogen fixing bacteria (NFB) are a good parameter to analyze the impacts of this fertigationon soil. We aimed to evaluate the distribution and diversity of AMF and NFB before and after applications of wastewater or manure from green line of a cattle slaughterhouse in the irrigation of B. brizantha cv Marandu in Cerrado soil and leaf biomass productivity. The experimental design was performed in completely randomized blocks with ten biofertigation managements. The seeds of the forage were distributed in grooves with spacing of $5 \mathrm{~cm}$. This seeds were covered with a soil layer. NFB and AMF diversity was performed by denaturing gradient gel electrophoresis (DGGE). The leaf biomass productivity in the biofertigation managements was higher than in the managements without the use wastewater/manure. After biofertigation managements, changes in the DGGE profile of the NFB and AMF communities were observed. These changes may be due to the difference in the sample collection period and in the soil humidification. Thus, these DGGE profiles was a good parameter to diagnose the efficacy of wastewater/manure as an alternative biotechnological irrigation.
\end{abstract}

Keywords: manure, meat, environmental impacts, Brachiaria brizantha, mycorrhizal, nitrofen fixing bacteria

\section{Introduction}

Cerrado in territorial extension is the second Brazilian biome with 204 million of hectares. This biome plays a fundamental role in the flows of the main hydrographic basins of south American (Lima \& Silva, 2007). Cerrado soils present edaphic conditions (e.g. texture, depth and relief) ideal for agropastoral activities. About $55 \%$ of Brazilian meat production is made in this biome (Embrapa, 2006). These activities have caused an increase in the deforestation of forest areas, in the water consumption and in the use of synthetic pesticides and fertilizers (da Silva et al., 2017).

Brazil has one of the largest cattle herds in the world, with about 215.2 million animals (IBGE, 2015). Eight million of these cattle are in the Cerrado of Tocantins state. Furthermore, the number of cattle slaughtered in this state is uncertain, due to clandestine slaughter and tax evasion. According to the IBGE (2015), this amount may ranges from 1 to 2 million animals.

In the cattle slaughterhouse, the highest water consumption is in the step of washing of animals, utensils and equipment. This step is made with fresh and potable water containing the minimum residual chlorine levels. This 
water consumption in the green line that corresponds to the process of cleaning stool, urine and vomit is about 1,000 liters per animal (Pacheco, 2006). Thus, in Tocantins/Brazil state the annual volume of wastewater of the green line is about 1 to 2 gigaliters.

Wastewater is an environmental problem if discarded untreated in soil or waterbodies (Hespanhol, 2002; Azevedo, 2007). However, they may be used as agricultural fertilizers, due to the nitrogen, phosphorus, potassium and organic matter contents (Hespanhol, 2002; Azevedo, 2007; Da Silva et al., 2017). In addition, the fertigation also provides the organic matter addition in the soil that is a nutrients source for plants, microorganisms and fauna.

The reduction of water consumption of natural waterbodies, of the wastewater disposal in environmental and of the application of synthetic fertilizers for pasture production is the main advantages of fertigation (Silva et al., 2016). This technology increases in plant productivity and in nutritional quality of biomass. According to Christofidis (2006), about 10 million hectares of Cerrado has potential for fertigation; but less than $10 \%$ was used, due to the conflicts of interest between the native human population, farmers and cattle ranchers (Lima et al., 2007).

The presence of fecal microorganisms (coliform bacteria, protozoa and helminths) in wastewater has also been a limiting factor for fertigation (Sousa Neto et al., 2012; Alderson et al., 2015; Ibekwe et al., 2018). However, water treatment and soil management can reduce the risk of contaminations of soil and of agronomic varieties by fecal microorganisms (Rocha et al., 2013; Silva et al., 2016). Fecal coliforms and helminth eggs were not identified, in the soil, after 60 days of the application of biosolid from the wastewater treatment (Rocha et al., 2003). Our study, it was done using the suggestion of Silva et al. (2016). These authors recommend the fertigation for the plantation of agronomic varieties that do not have direct use as human food. In addition, these pathogenic microorganisms from wastewater can also be a source of nutrients for soil microorganisms. According to Ibekwe et al. (2018), bacterial of treated wastewater are very active in soil functions. Pyrosequencing detected sequences of nitrifying bacteria, nitrogen-fixing bacteria, denitrifying bacteria, potential pathogens, and fecal indicator bacteria in treated wastewater (Ibekwe et al., 2018). These authors also show that microbial diversity was not significantly different between soils with treated wastewater and fresh water by Shannon diversity index.

The soil microorganism has several biological activities, such as, organic matter decomposition, atmospheric nitrogen fixation, nitrification and solubilization, and minerals availability to plants (Moreira \& Siqueira, 2006; Madigan et al., 2010). In addition, Silva et al. (2016) showed that arbuscular mycorrhizal fungi (AMF) and nitrogen fixing bacteria (NFB) are a good parameter to analyze the impacts of fertigation with domestic wastewater in the Brachiaria brizantha planting in Cerrado soil.

The occurrence and distribution of AMF are influenced by soil use and edaphic factors (Silva et al., 2015). These fungi provide the plant with an increase in rate of nutrient absorption and tolerance to heavy metals, water stress and pathogenic microorganisms (Guo et al., 2013). The genus Glomus is the most abundant in the areas of intensive and extensive pasture and in no-tillage and conventional. In addition, no-tillage provides greatest abundance of AMF spores (Silva et al., 2015).

The soil nitrogen is obtained from the degradation and mineralization of organic matter, biological nitrogen fixation (BNF) and fertilizers (Bloom, 2015). The highest nitrogen content in the rhizosphere comes from the symbiosis between the plants and the diazotrophic bacteria (Vance, 1998; Wartiainen et al., 2008; Silveira et al., 2013).

Thus, the aims of this study were to evaluate the distribution and diversity of AMF and NFB before and after applications of wastewater or manure from green line of a cattle slaughterhouse in the irrigation of Brachiaria brizantha cv Marandu in Cerrado soil and leaf biomass productivity.

\section{Materialsand Methods}

\subsection{Site Location and Characterization}

The experiment was carried out on the campus of CEULP/ULBRA, Palmas-Tocantins, Brazil, located at an altitude of $254 \mathrm{~m}$ and the following geographic coordinates: $10^{\circ} 16^{\prime} 34.16^{\prime \prime} \mathrm{S}$ and $48^{\circ} 20^{\prime} 05.03^{\prime \prime} \mathrm{W}$ (Figure 1). 


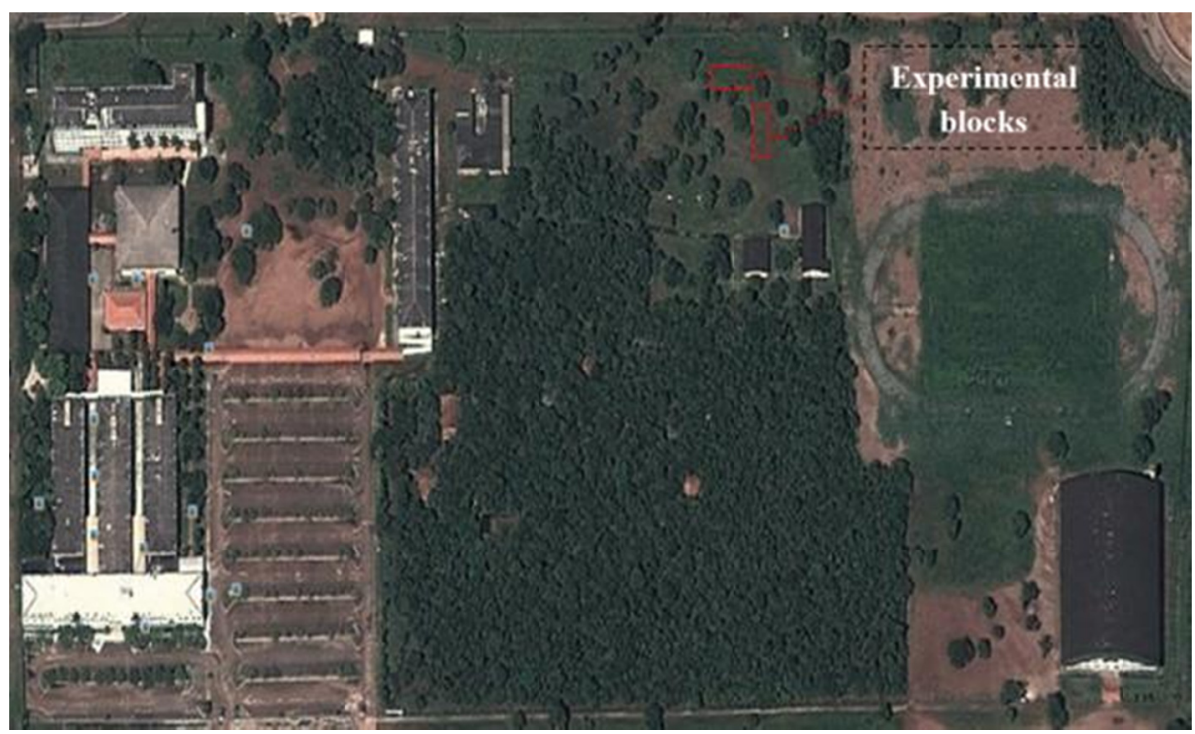

Figure 1. Experimental area showing the distribution blocks (B1 to B4)

Source: Google Earth.

The climate of this region is humid and subhumid (C2wA"a") with a water deficit in the winter and annual evapotranspiration between 1,400 and 1,700 $\mathrm{mm}$ (Sousa, 2010).

The soil of this experiment was classified as a Red-Yellow Latosol, occurring in a smooth relief and a slope $<$ $5 \%$. Thus, surface runoff is slow to light and predominantly westbound (Seplan, 2013a).

\subsection{The Experiment}

First, vegetation cover was removed,and soil sampling was performed to the soil characterization. Soil sampling was systematic according to the methodology proposed by Raij (2001). Eight samples (A1 to A8) were collected at depths of 0 to 10, 10 to 20, 20 to 30 and 90 to $100 \mathrm{~cm}$ (Figure 1).

Ten treatments of biofertigation managements (M1 to M10) were applied on plots of $1.62 \times 3.00 \mathrm{~m}$ (total of 4.86 $\mathrm{m}^{2}$ ) spaced $0.20 \mathrm{~m}$ apart, in quadruplicate (Figure 1). Forage was planted in lines spaced $1.00 \mathrm{~m}$ inside the plots.

The experiment was arranged in a randomized complete block design with four replications (B1 to B4), two aligned east to west, and two north to south (Figure 1).

At the end of the experiment, which occurred after the third cut of plant, new soil samples were obtained. These samples were collected at the center of each experimental plot (M1 to M10). In these collection points, soil resistance to root penetration in depths of 0 to $60 \mathrm{~cm}$ and $2.5 \mathrm{~cm}$ interval was measured with the aid of the penetrometer (Falker-PLG 1020).

Soil samples ( $20 \mathrm{~g}$ ) were used to analyze the physical-chemical indicators (see item 2.4).

\subsubsection{Preparation Initial of Soil in Experimental Area}

After the step of collecting the soil samples, the operation of plowing and sorting of the soil with the use of tractor-driven disk plows was performed.

The values of the physical-chemical indicators ( $\mathrm{pH}$, base saturation and cation exchange capacity) of the soil samples collected prior to the installation of the experiment were used to the soil acidity adjustment. The distribution and incorporation dolomitic limestone in the area was performed, respectively, by hand-throwing and use of rake. In addition, during the acidity, the area leveling was also performed.

The application of the limestone occurred during the dry period with few or no rain in July/2015. Thus, a water layer was applied in soil for a better distribution of the limestone in area.

\subsubsection{Forage Nutritional Demand}

The primary macronutrients, nitrogen $(\mathrm{N})$, phosphorus pentoxide (P2O5) and potassium oxide (K20) were used to determine the nutritional demand of $B$. brizantha. The each nutrient amount was determined from the contents 
of these elements in the depth of 0 to $20 \mathrm{~cm}$ and commercial fertilizer containing superphosphate (with $18 \%$ $\mathrm{P}_{2} \mathrm{O}_{5}$ ), potassium chloride (with $60 \% \mathrm{~K}_{2} \mathrm{O}$ ) and urea (with $45 \% \mathrm{~N}$ ) was used. Nitrogen and others elements were determined, respectively, the Kjedahl method and spectrophotometry (APHA, 2005; Embrapa, 2006).

\subsubsection{Forage Water Demand}

In the pre-planting, a day before the beginning of sowing of the weed on June 22, 2015, a water layer in the experimental plots was applied to raise the water level in the soil to the field capacity. This water layer was calculated from the estimate of the water depth in the soil between the wilting point and the field capacity. After this first addition of water in the soil, the other additions were estimated as a function of the maximum crop evapotranspiration, the irrigation shift ( 3 and 4 days) and the precipitation occurred between biofertigation.

In each biofertigation and in the experimental plots, the water layer that was applied, with or without wastewater/manure was multiplied by the plot area. This volume of water was divided by the capacity of the sprinkler $(10 \mathrm{~L})$ to determine the number of sprinklers to be applied in each plot.

\subsection{Fodder Planting}

B. brizantha cv Marandu seed was purchased in Palmas/TO/Brazil with, respectively, $60.3 \%$ and $80.0 \%$ purity and germination rate. Thus, the cultural value was $48.24 \%$. In the planting of this forage are used of 1.5 to 2.0 $\mathrm{kg} / \mathrm{ha}$ of viable seeds (Embrapa, 1984). In this study, $1.75 \mathrm{~kg} / \mathrm{ha}$ of viable seeds were used.

The planting was done (June 24, 2015) with sowing in equidistant lines $(1.00 \mathrm{~m})$. In each plot three planting lines were made in the form of triangular grooves with depth of $4 \mathrm{~cm}$ and $1.62 \mathrm{~m}$ in length. The seeds were distributed in these grooves with spacing of $5 \mathrm{~cm}$ and were covered with a lightly pressed soil layer. This cover was made only to provide wet soil contact with the seeds.

\subsection{Biofertigation Management in the Field Experiment}

The experimental design was performed in completely randomized blocks (B1 to B4) and 10 biofertigation management (M1 to M10) (Table 1). This table also contains the quantity of inputs for each management.

The wastewater used in this experiment were collected in a cattle slaughterhouse located in Paraíso do Tocantins/TO/Brazil. In this slaughterhouse, the effluents of the green line are channeled to a reception box. The wastewater of this box are separated into two portions through a pumping system. The liquid part is deposited in three stabilization ponds and solid part (manure), is used as fuel in the boiler heating system.

For the composition of the biofertigation management, the wastewater of slaughterhouse from the $3^{\text {rd }}$ stabilization pond (M3 a M5), from reception box (M6 a M8) and of solid part (M9 e M10) were used (Table 1). The managements M1 and M2 did not contain wastewater of slaughterhouse (Table 1).

Samples of each of these wastewater of slaughterhouse were collected for determination of the physical-chemical indicators (Table 2). These analyses were made according to Standard Methods (APHA, 2005). 
Table 1. Biofertigation management and quantity of wastewater/manure applied in the planting of Brachiaria brizantha cv Marandu

\begin{tabular}{|c|c|c|c|c|}
\hline & & \multicolumn{3}{|c|}{ Wastewater per parcels } \\
\hline \multicolumn{2}{|c|}{ Biofertigation management } & \multirow{2}{*}{$\begin{array}{l}3^{\text {rd }} \text { stabilization } \\
\text { ponds (lt) } \\
0\end{array}$} & \multirow{2}{*}{$\begin{array}{l}\text { Reception } \\
\text { box (lt) } \\
0\end{array}$} & \multirow{2}{*}{$\begin{array}{l}\text { Manure (kg) } \\
0\end{array}$} \\
\hline M1 & Application of dolomitic limestone and water blade of artesian well & & & \\
\hline M2 & $\begin{array}{l}\text { Application of dolomitic limestone, NPK fertilizer (commercial) and water blade of } \\
\text { artesian well. }\end{array}$ & 0 & 0 & 0 \\
\hline M3 & $\begin{array}{l}\text { Application of dolomitic limestone, fertilizer: } \mathrm{N}(80 \% \text { commercial and } 20 \% \text { of } \\
\text { wastewater of the } 3^{\text {rd }} \text { stabilization ponds), } \mathrm{P} \text { and } \mathrm{K} \text { and water blade of artesian well }\end{array}$ & 98 & 0 & 0 \\
\hline M4 & $\begin{array}{l}\text { Application of dolomitic limestone, fertilizer: } \mathrm{N}(60 \% \text { commercial and } 40 \% \text { of } \\
\text { wastewater of the } 3^{\text {rd }} \text { stabilization ponds), } \mathrm{P} \text { and } \mathrm{K} \text { and water blade of artesian well }\end{array}$ & 196 & 0 & 0 \\
\hline M5 & $\begin{array}{l}\text { Application of dolomitic limestone, fertilizer: } \mathrm{N}(40 \% \text { commercial and } 60 \% \text { of } \\
\text { wastewater of the } 3^{\text {rd }} \text { stabilization ponds), } \mathrm{P} \text { and } \mathrm{K} \text { and water blade of artesian well }\end{array}$ & 293 & 0 & 0 \\
\hline M6 & $\begin{array}{l}\text { Application of dolomitic limestone, fertilizer: } \mathrm{N}(80 \% \text { commercial and } 20 \% \text { of } \\
\text { wastewater of the reception box), } \mathrm{P} \text { and } \mathrm{K} \text { and water blade of artesian well. }\end{array}$ & 0 & 85 & 0 \\
\hline M7 & $\begin{array}{l}\text { Application of dolomitic limestone, fertilizer: } \mathrm{N}(60 \% \text { commercial and } 40 \% \text { of } \\
\text { wastewater of the reception box), } \mathrm{P} \text { and } \mathrm{K} \text { and water blade of artesian well }\end{array}$ & 0 & 170 & 0 \\
\hline M8 & $\begin{array}{l}\text { Application of dolomitic limestone, fertilizer: } \mathrm{N} \text { ( } 40 \% \text { commercial and } 60 \% \text { of } \\
\text { wastewater of the reception box), } \mathrm{P} \text { and } \mathrm{K} \text { and water blade of artesian well }\end{array}$ & 0 & 254 & 0 \\
\hline M9 & $\begin{array}{l}\text { Application of dolomitic limestone, fertilizer: } \mathrm{N}(80 \% \text { commercial and } 20 \% \\
\text { manure), } \mathrm{P} \text { and } \mathrm{K} \text { and water blade of artesian well }\end{array}$ & 0 & 0 & 33 \\
\hline M10 & $\begin{array}{l}\text { Application of dolomitic limestone, fertilizer: } \mathrm{N}(60 \% \text { commercial and } 40 \% \\
\text { manure), } \mathrm{P} \text { and } \mathrm{K} \text { and water blade of artesian well }\end{array}$ & 0 & 0 & 66 \\
\hline
\end{tabular}

Note. N: nitrogen, P: phosphorus, K: potassium.

The inputs amount of each parcels was determined by the availability of NPK in the soil and in the wastewater of slaughterhouse (Table 2). In addition, the $\mathrm{N}$ content was used to determine the wastewater of slaughterhouse amount to be applied in the biofertigation management (Tables 1 and 2).

The commercial and wastewater of slaughterhouse inputs were applied together with the water layer of artesian well.

Table 2. Physical-chemical indicators concentration before of the planting Brachiaria brizantha cv Marandu and biofertigation management (M1 at M10) with wastewater/manure of the green line

\begin{tabular}{|c|c|c|c|}
\hline \multirow{2}{*}{ Physical-chemical indicators* } & \multicolumn{3}{|c|}{ Wastewater/manure of slaughterhouse } \\
\hline & $3^{\text {rd }}$ stabilization ponds & Reception box & Manure \\
\hline & \multicolumn{2}{|c|}{ 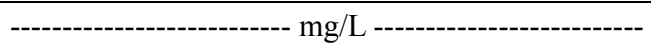 } & ------- mg/kg ------- \\
\hline Carbon & 2034 & 2534 & 5322 \\
\hline Nitrogen & 149.44 & 172.33 & 443.79 \\
\hline Phosphorus & 1.58 & 1.982 & 4.55 \\
\hline Potasium & 14.22 & 21.421 & 1.62 \\
\hline Sodium & 27.12 & 39.252 & 3.21 \\
\hline $\mathrm{pH}$ & 8.20 & 8.05 & 8.76 \\
\hline
\end{tabular}

Note. ${ }^{*}$ The minerals were determined after a nitroperchloric digestion of the samples.

\subsection{Characterization of Leaf Biomass}

The cut of leaf biomass were made with a pruning shears. The samples of these biomass were collected in the center of the parcels, with $1.00 \mathrm{~m} \times 0.82 \mathrm{~m}$ of dimensions to avoid the border effect. The green mass was determined on analytical balance.The samples in $65{ }^{\circ} \mathrm{C}$ forced-ventilation greenhouses during 72 hours to 
moisture loss were conditioned. After cooling to room temperature $\left(25 \pm 5^{\circ} \mathrm{C}\right)$, the air dry mass (ADM) was determined using the analytical balance. This ADM was crushed with the aid of a Willey mill for determination of greenhouse dry mass (GDM) at $105^{\circ} \mathrm{C}$.

\subsection{Analysis of the Microbiota in the Biofertigation Management}

\subsubsection{Measurement of Viable Microorganisms in Soil}

Ten grams of soil and $90 \mathrm{~mL}$ of sodium chloride $(0.85 \% \mathrm{w} / \mathrm{v})$ were used to quantify the microorganisms (Sabino, 2007). This mixture was stirred for one hour at $200 \mathrm{rpm}$, filtered on filter paper and stored at $4{ }^{\circ} \mathrm{C}$. A series of dilutions $\left(10^{-1}\right.$ to $\left.10^{-7}\right)$ of $1 \mathrm{~mL}$ of the suspension was made. One hundred $\mu 1$ of each dilution was added on solid culture medium and spread with a Drigalski handle. The plates were incubated at $25{ }^{\circ} \mathrm{C}$. This procedure was performed in triplicates.

In the measurement of BFN, the nutrient agar culture medium containing $0.3 \mathrm{ml}$ of nystatin was used (Sabino, 2007). The $\mathrm{pH}$ in this medium culture was adjusted to 7 . The plates were incubated for 3 days.

Martin medium containing rose bengal $(0.1 \% \mathrm{w} / \mathrm{v})$ was used for counting filamentous fungi (Martin, 1950). In this medium, $1 \mathrm{ml}$ of streptomycin $(0.3 \mathrm{mg} / \mathrm{ml})$ was added and the $\mathrm{pH}$ was adjusted to 5.8 . The plates were incubated for 7 days.

The actinomycete counts in selective medium containing glycerol were made (Rodrigues, 2007). The plates for 7 days were incubated.

The microbial measurements were expressed in log scale of the colony-forming unit (CFU) per gram of soil.

\subsubsection{Characterization of Microbial Diversity by DGGE Profile}

Diversity of NFB and AMF was performed by denaturing gradient gel electrophoresis (DGGE). These microbial groups were selected for this analysis due to species diversity and their contributions to soil fertility and structuring (Moreira \& Siqueira, 2006).

DNA of the soil samples was extracted using a soil DNA Mega Prep Kit (Kit-MO BIO, Ultraclean TM). In this extraction, $0.5 \mathrm{~g}$ of soil were added in plastic tubes (Eppendorff type) containing polypropylene beads. After, several steps of adding solutions and centrifugations, according to the manufacturer's protocol, the suspension containing the total DNA was stored at $-20{ }^{\circ} \mathrm{C}$.

The nifH and $18 S$ rDNA genes were amplified by polymerase chain reaction (PCR) from the total DNA for analysis of NFB and AMF, respectively.

Bionumerics software (Version 5.10) was used for normalization, conversion and comparison of the images in presence/absence and band intensity matrices.

\subsubsection{DGGE Profile of NFB}

The PCR of the nifH gene was done with the 19F and 407R primers (Ueda et al., 1995). In this amplification, a 390 base pair (bp) fragment was obtained. This fragment was used in the Nested-PCR with the 19F-GC (with GC clamp) and 278R primers (Direito \& Teixeira, 2002). In this new amplification, a $260 \mathrm{bp}$ fragment was obtained.

PCRs were performed with a final volume of $50 \mu \mathrm{l}$, containing $1 \mu \mathrm{l}(20 \mathrm{ng})$ of total DNA, $0.2 \mu \mathrm{M}$ of primers, $200 \mu \mathrm{M}$ of triphosphate deoxyribonucleotides, $2 \mathrm{mM}$ magnesium chloride, $0.5 \mathrm{mg} \mathrm{ml}^{-1}$ of bovine serum albumin, $50 \mathrm{mM}$ of potassium chloride and 1.25 U of GO Taq DNA polymerase (Invitrogen, Life Technologies) in 20 $\mathrm{mM}$ of Tris- $\mathrm{HCl}(\mathrm{pH} 8.4)$.

The program used in the thermal cycler was similar to the described by Direito and Teixeira (2002). In the negative controls, $1 \mu \mathrm{L}$ of MilliQ water was used instead of the DNA fragments.

The Nested-PCR fragments were analyzed by DGGE (Model DCodeTM Systems, BIO-RAD California). $20 \mu \mathrm{L}$ of these fragments were loaded onto $8 \%$ polyacrylamide gel $(\mathrm{w} / \mathrm{v})$ in TAE buffer $(1 \times)$. This gel was prepared with denaturation gradient varying from 45 to $70 \%$ using urea (7M) and formamide. The gel was subjected to vertical electrophoresis for $12 \mathrm{~h}$ at $60 \mathrm{~V}$ and $60^{\circ} \mathrm{C}$. This gel was stained for 40 min with SYBR Gold (1×) (Molecular Probes, Leiden, The Netherlands) and photographed on ultraviolet light on the Molecular Imaging Locococentor (Loccus biotechnological L-Pix Chemi).

\subsubsection{DGGE Profile of AMF}

PCR was similar to those described in DDGE profile of NFB. 
The AM1 and NS31 primers were used to amplify the fragments of the 18S rDNA gene of the first PCR (Simon et al., 1992; Helgason et al., 1998). In this reaction, a 580 bp fragment was obtained which was used in the Nested-PCR with primers NS31-GC (with GC clamp) and Glo1 (Kowalchuk et al., 2002; Cornejo et al., 2004).

The DNA fragments of the Nested-PCR were used to obtain the DGGE profile (DCodeTM Systems Model, BIO-RAD California). Twenty $\mu \mathrm{L}$ of this fragment (150 to $200 \mathrm{ng}$ of DNA) was loaded onto polyacrylamide gel $(8 \%, w / v)$ in TAE buffer $(1 \times)$.

The next steps to obtain DDGE prolife of AMF were done similar to DGGE prolife of NFB.

\subsection{Statistical Analysis of the Indicators of Soil Quality and of Leaf Biomass}

The experiment was conducted in a completely randomized block design with factorial unfolding (10 biofertigation management and 3 cuts of leaf biomass).

Physical-chemical indicators content and leaf biomass were compared using analysis of variance followed by pos-hocTukey test, both at $5 \%$ significance. The estimates of these parameters were made at $95 \%$ confidence level, based on the coefficient of variation (CV) limits proposed by Pimentel-Gomes (2000). This author classifies the experimental variations in low variation $(\mathrm{CV}<10 \%)$, medium $(10<\mathrm{CV}<20 \%)$, high $(20<\mathrm{CV}<$ at $30 \%)$, and very high $(\mathrm{CV}>30 \%)$.

The DGGE profiles were analyzed in the Bionumerics software (Version 5.1). In this software were made the unweighted pair group method with arithmetic mean (UPGMA) dendograms using the Jaccard similarity index. The similar bands were considered those with probability level of $0.5 \%$ by the post-hoc Bonferroni test.

The graphs to present the relationships between the variables were made from the spreadsheets/software: Excel, Surfer, SigmaPLOT12.0 and Minitab 17.

\section{Results and Discussions}

\subsection{Analyzes Carried out Before Biofertigation Management}

\subsubsection{Wastewater/Manure of Slaughterhouse Composition}

The wastewater/manure of slaughterhouse had a diversified composition of primary macronutrients (Table 2). Thus, crude wastewater, despite representing an environmental problem may be reduces or eliminates the use of commercial fertilizers (Hespanhol, 2002).

Forage grasses due to accelerated leaf growth rates require a large nutrient amount (Barbero et al., 2013; Costa et al., 2016). Thus, the use of wastewater in meeting the demand of these plants is a viable alternative (Silva et al., 2016, 2017).

A forage crop with high availability in nitrogen has more vigorous roots than a crop deficient in this nutrient, because root growth is related to the accumulation of elaborated sap (Brower, 1962).

The sodium had lower concentrations (Table 2) than at the limit level $(40 \mathrm{mg} / \mathrm{L})$, recommended to avoid salinization or sodification of soil and groundwater (Von Sperling, 2005; Gloaguen, Gonçalves, Forti, Lucas, \& Montes, 2010).

The basic $\mathrm{pH}$ of wastewater/manure of green line (Table 2) can contribute to the increase of the cation exchange capacity in the soil and together with the limestone increase the $\mathrm{pH}$ in soil solution. These soil changes may favor the development of forage crops and shows the potential of biofertigation with wastewater/manure of green line.

\subsubsection{Characterization of Physical-Chemical Indicators of Soil}

The concentration, movement and distribution of the physical-chemical indicators in natural conditions limit the use of the Cerrado soil for the exploitation of agropastoral activities. The use of adjusts acidity and fertilizeris are alternative to reduce or eliminate this limitation. Thus, in this study the dolomitic limestone was added for soil acidity adjustment before the planting of $B$. brizantha $\mathrm{cv}$ Marandu.

We observed a reduction in the ions $(\mathrm{H}+\mathrm{Al})$ concentration and an increase in base saturation and $\mathrm{pH}$ in the effective depth $(20$ to $30 \mathrm{~cm}$ ) of the roots (Figure 2). These results may be due to the morphological characteristics of the sandy loam soil. In this type of soil has a greatest volume of infiltration of water in the roots depth that favors the leaching of the bases and the increase of the $\mathrm{H}^{+}$and $\mathrm{Al}^{3+}$ concentration.

The $\mathrm{pH}$ in the soil depth of 0 to $30 \mathrm{~cm}$ did not significant difference $(\mathrm{p}<0.05)$ in the blocks. However, in the depth of 90 to $100 \mathrm{~cm}$ the $\mathrm{pH}$ presented a significant difference when compared to the other depths (Figure 2). 
Cerrado soils have acidic $\mathrm{pH}$ and vary according to the time, geographical location and soil depth (Ronquim, 2010).

Table 3. Counts of viable microbial cells of the Cerrado soil before the planting of Brachiaria brizantha cv Marandu and of the use of biofertigation with cattle slaughterhouse wastewater/manure

\begin{tabular}{|c|c|c|c|c|}
\hline Sample collection points & Soil depth & Actinomycete & Total bacteria & Fungi \\
\hline & --------- cm-------- & ------------------ & $-\log _{(\mathrm{CFU}} \mathrm{g}^{-}$ & 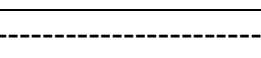 \\
\hline \multirow[t]{4}{*}{ A1 } & $0-10$ & $6.19 \pm 0.01$ & $7.39 \pm 0.01$ & $5.25 \pm 0.01$ \\
\hline & $10-20$ & $6.06 \pm 0.01$ & $7.31 \pm 0.01$ & $5.10 \pm 0.03$ \\
\hline & $20-30$ & $5.97 \pm 0.01$ & $7.21 \pm 0.02$ & $-^{\mathrm{a}}$ \\
\hline & $90-100$ & $5.40 \pm 0.04$ & $6.70 \pm 0.02$ & $-{ }^{a}$ \\
\hline \multirow[t]{4}{*}{$\mathrm{A} 2$} & $0-10$ & $6.19 \pm 0.01$ & $7.37 \pm 0.01$ & $4.97 \pm 0.02$ \\
\hline & $10-20$ & $6.02 \pm 0.01$ & $7.27 \pm 0.02$ & $4.80 \pm 0.03$ \\
\hline & $20-30$ & $5.97 \pm 0.01$ & $6.91 \pm 0.01$ & $-{ }^{a}$ \\
\hline & $90-100$ & $-^{\mathrm{a}}$ & $6.64 \pm 0.01$ & $-{ }^{a}$ \\
\hline \multirow[t]{4}{*}{$\mathrm{A} 3$} & $0-10$ & $6.17 \pm 0.01$ & $7.32 \pm 0.02$ & $5.10 \pm 0.02$ \\
\hline & $10-20$ & $6.06 \pm 0.01$ & $7.27 \pm 0.01$ & $4.91 \pm 0.01$ \\
\hline & $20-30$ & $5.99 \pm 0.01$ & $6.97 \pm 0.01$ & $\mathrm{-a}^{\mathrm{a}}$ \\
\hline & $90-100$ & $5.41 \pm 0.04$ & $6.52 \pm 0.03$ & $-^{\mathrm{a}}$ \\
\hline \multirow[t]{4}{*}{ A4 } & $0-10$ & $6.25 \pm 0.01$ & $7.42 \pm 0.01$ & $4.81 \pm 0.03$ \\
\hline & $10-20$ & $6.13 \pm 0.01$ & $7.28 \pm 0.01$ & $4.66 \pm 0.04$ \\
\hline & $20-30$ & $5.94 \pm 0.01$ & $6.94 \pm 0.02$ & $-^{\mathrm{a}}$ \\
\hline & $90-100$ & $-^{\mathrm{a}}$ & $6.51 \pm 0.03$ & $-{ }^{a}$ \\
\hline \multirow[t]{4}{*}{ A5 } & $0-10$ & $6.18 \pm 0.01$ & $7.37 \pm 0.01$ & $5.02 \pm 0.03$ \\
\hline & $10-20$ & $5.98 \pm 0.01$ & $7.26 \pm 0.01$ & $4.62 \pm 0.03$ \\
\hline & $20-30$ & $5.67 \pm 0.01$ & $6.94 \pm 0.01$ & $-{ }^{a}$ \\
\hline & $90-100$ & $\mathrm{-a}^{\mathrm{a}}$ & $6.55 \pm 0.03$ & $-^{\mathrm{a}}$ \\
\hline \multirow[t]{4}{*}{ A6 } & $0-10$ & $6.18 \pm 0.01$ & $7.45 \pm 0.01$ & $4.87 \pm 0.02$ \\
\hline & $10-20$ & $5.93 \pm 0.02$ & $7.29 \pm 0.02$ & $4.63 \pm 0.03$ \\
\hline & $20-30$ & $5.66 \pm 0.02$ & $6.88 \pm 0.03$ & $-^{a}$ \\
\hline & $90-100$ & $-^{\mathrm{a}}$ & $6.53 \pm 0.03$ & $-^{a}$ \\
\hline \multirow[t]{4}{*}{ A7 } & $0-10$ & $6.16 \pm 0.01$ & $7.22 \pm 0.01$ & $4.79 \pm 0.02$ \\
\hline & $10-20$ & $5.87 \pm 0.02$ & $7.16 \pm 0.01$ & $4.67 \pm 0.04$ \\
\hline & $20-30$ & $5.54 \pm 0.02$ & $6.89 \pm 0.01$ & $-^{\mathrm{a}}$ \\
\hline & $90-100$ & $-^{a}$ & $6.54 \pm 0.03$ & $-{ }^{a}$ \\
\hline \multirow[t]{4}{*}{ A8 } & $0-10$ & $5.99 \pm 0.01$ & $7.25 \pm 0.01$ & $5.00 \pm 0.02$ \\
\hline & $10-20$ & $5.89 \pm 0.01$ & $7.10 \pm 0.02$ & $4.89 \pm 0.02$ \\
\hline & $20-30$ & $5.56 \pm 0.02$ & $6.79 \pm 0.01$ & $-^{\mathrm{a}}$ \\
\hline & $90-100$ & $\mathrm{-}^{\mathrm{a}}$ & $6.45 \pm 0.02$ & $\mathrm{a}^{\mathrm{a}}$ \\
\hline
\end{tabular}

Note. a: values below 25 colonies. CFU: colony-forming unit. B1P1: sample collection points 1 and soil depth 1 $(0-10 \mathrm{~cm}), \mathrm{B} 2 \mathrm{P} 2$ : sample collection point 2 and soil depth $2(10-20 \mathrm{~cm}), \mathrm{B} 3 \mathrm{P} 3$ : sample collection point 3 and soil depth $3(20-30 \mathrm{~cm})$ and B4P4: sample collection point 4 and soil depth $4(90-100 \mathrm{~cm})$. 


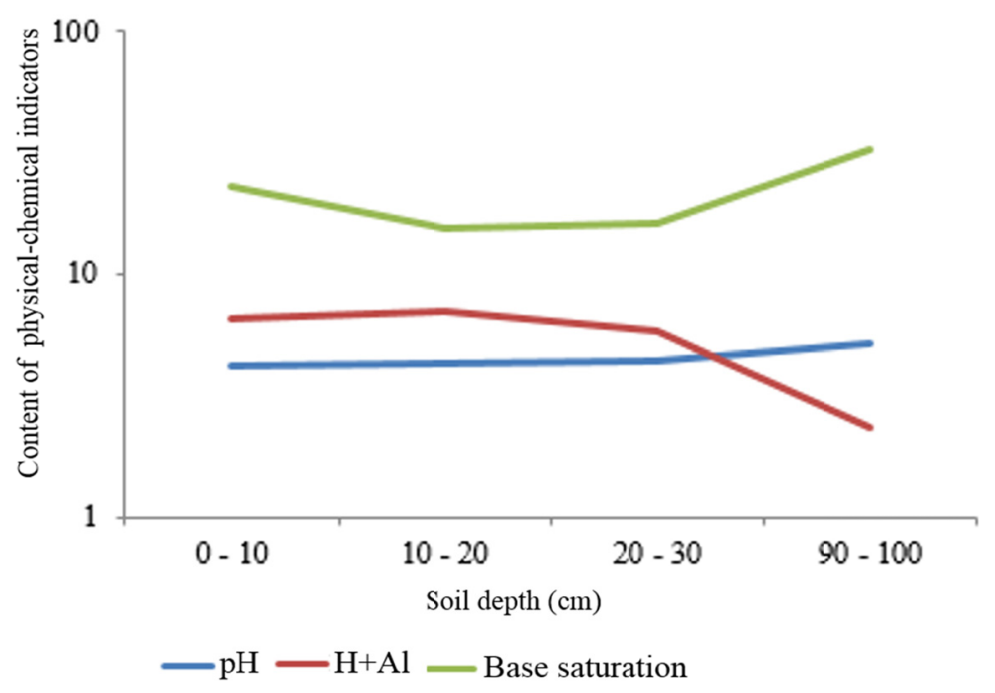

Figure 2. Physical-chemical indicators in the soil deth of 0-10 at 90-100 cm in experimental area before of the planting Brachiaria brizantha cv Marandu

\subsubsection{Measurement of Viable Microorganisms in Soil}

At all sample collection points and depth, we observed viable microbial cells showing the distribution of microbial cells throughout the experimental area (Figure 3, table 3). This density of microorganisms by soil mass reduced in function of the depth that may be due to nutrient and oxygen limitation (Moreira \& Siqueira, 2006). According to Vale Júnior (2011), the microorganisms concentration is greatest at depth of up to $20 \mathrm{~cm}$.

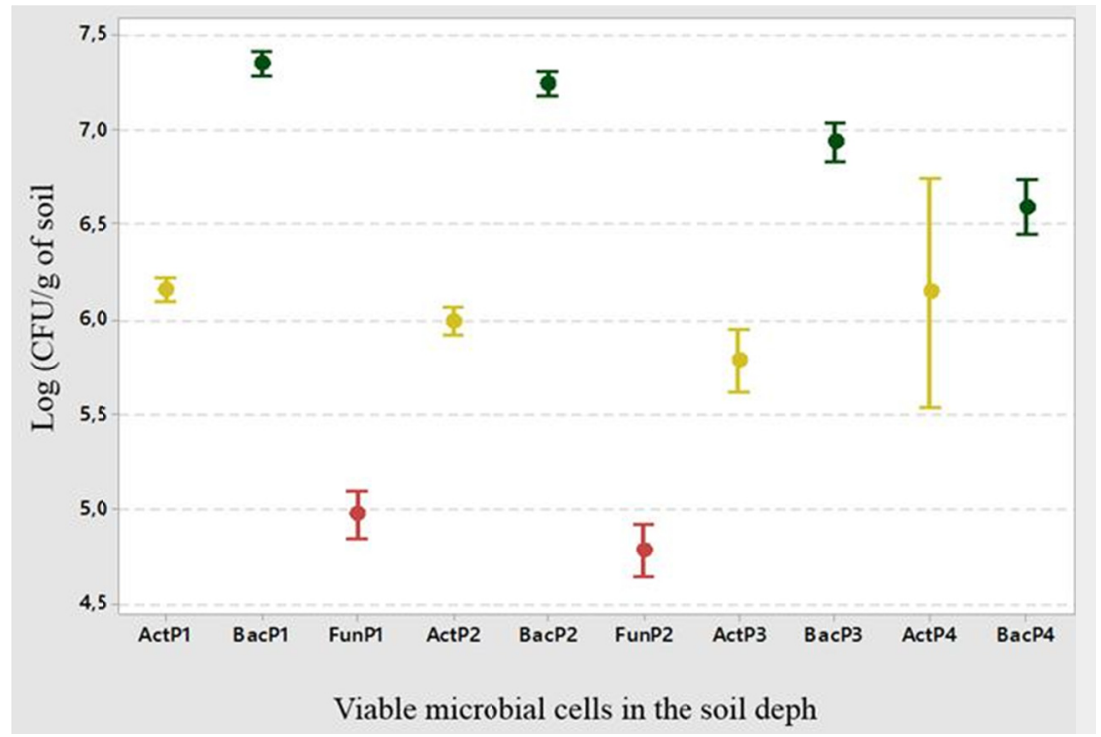

Figure 3. Microbial cell counts (Act: Actinomycete, Bac: Bacteria, Fun: Fungus) at different depths (P1 to P4) in the Cerrado soil before planting of Brachiaria brizantha cv Marandu and of the use of biofertigation with cattle slaughterhouse wastewater/manure

At the same depth no significant difference was observed in the count of microbial cells $(\mathrm{p}<0.05)$. This similarity between sample collection sites may be due to the size and topography of the experimental area. The total area $\left(252 \mathrm{~m}^{2}\right)$ was divided into two subareas with dimensions of $7 \mathrm{~m}$ by $18 \mathrm{~m}$. In each subarea, the sampling points had a spacing of $3.5 \mathrm{~m}$ with a dimension of $9.0 \mathrm{~m}$. The experimental area showed a slope of less than $5 \%$, which contributes to a homogeneous distribution of the cells and microbial spores in the experimental area. 
Regardless of the sample collection points and the soil depth, the amount of viable bacterial cells was higher than to the fungi (Figure 3). This result may be due to the bacteria had several ecological niches with aerobic, obligatory anaerobic, facultative anaerobic and nitrogen fixation species (Dunbar et al., 2002; Zehr, et al., 2003).

Only at collection points A1 and A3 it was observed actinomycete colonies at depth of 90-100 cm (Table 3). However, this prokaryotic group has a wide distribution throughout the experimental area that shows the potential of nitrogen fixing species (Figure 3). Silva (2017) has also observed the presence of viable actinomycete cells in depths of up to $30 \mathrm{~cm}$ in Cerrado soil.

Fungal colonies were identified only at depths of $0-10 \mathrm{~cm}$ and $10-20 \mathrm{~cm}$ (Figure 3, Table 3). The absence of viable cells of this microorganism in depth below $20 \mathrm{~cm}$ may be due to limitation of nutrients and oxygen. Other authors have shown that fungal cells are found in big amounts in the rhizosphere that it has highest nutrient and water availability (Smith et al., 2010; Neeraj, 2011).

\subsubsection{Characterization of Microbial Diversity by DGGE Profile}

The DGGE profile shows the presence of a large amount and intensity of nifH gene bands before to biofertigation (Figure 4). This result confirms those of the viable microbial cell count, which showed a high microbial cell density per gram of soil (Table 3). In addition, the presence of the nifH gene shows the richness and abundance of NFB in the experimental area (Figure 4).

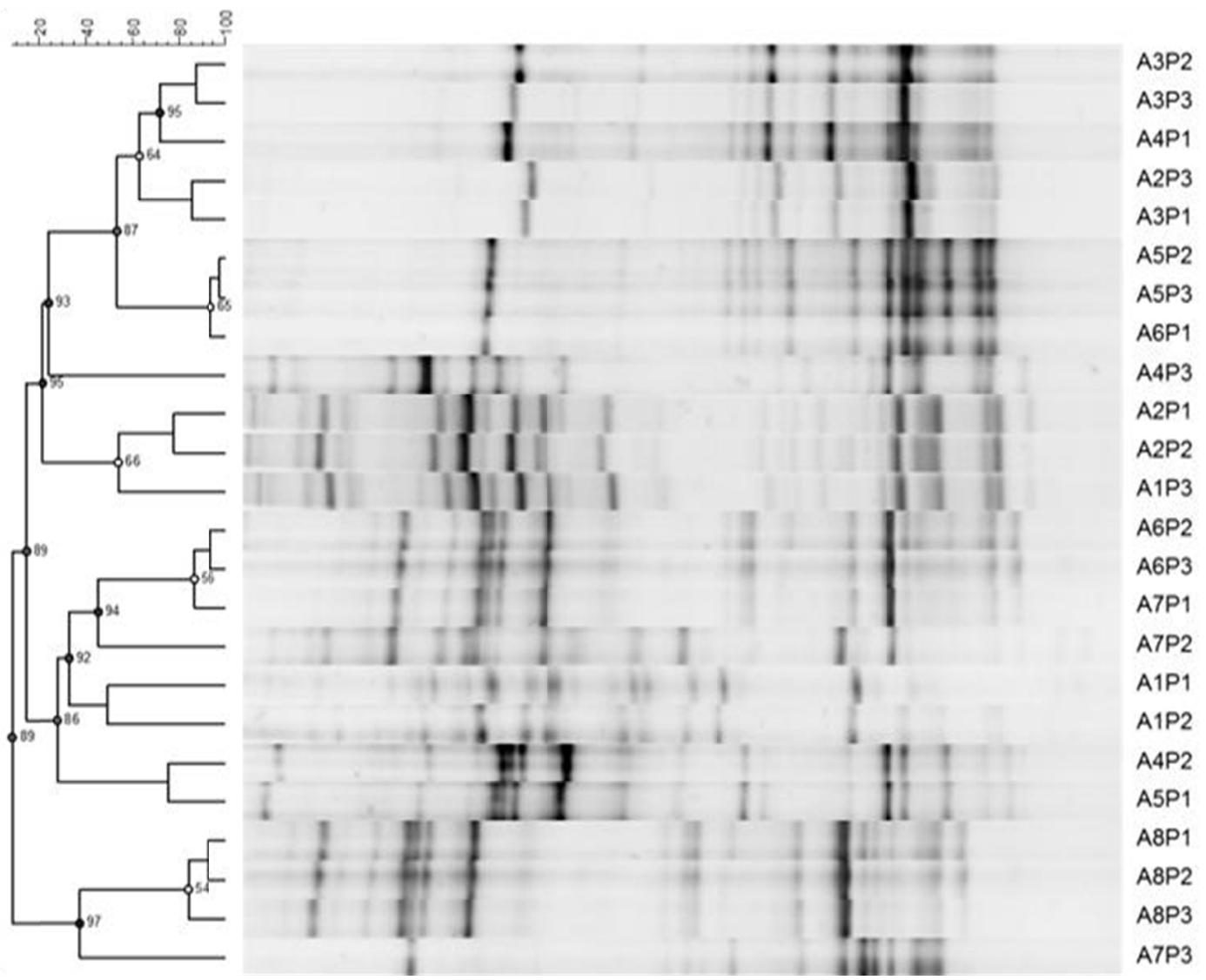

Figure 4. UPGMA dendogram and DGGE profile of $n i f \mathrm{H}$ gene from Cerrado soil before the use of biofertigation with wastewater/manure from cattle slaughterhouse. A1P1: sample collection point 1 and soil depth $1(0-10 \mathrm{~cm})$, A1P2: sample collection point 1 and soil depth $2(10-20 \mathrm{~cm}), \mathrm{A} 1 \mathrm{P} 3$ : sample collection point 1 and soil depth 3 $(20-30 \mathrm{~cm}), \mathrm{A} 2$ : sample collection point 2 and so on until A8

The UPGMA dendogram did not group the sample collection points and the soil depths by similarity of the nifH gene bands (Figure 4). This showed a heterogeneous distribution of this microbial group in the Cerrado soil.

The diversity of NFB was greater than that of AMF (Figures 4 and 5). This result was also observed in the counts of viable microbial cells that can be due to the unicellular growth of the bacteria. In the sample composition, it 
there is a greater probability of obtaining bacterial cells than of filamentous fungi. In addition, the UPMGA dendograms showed a heterogeneous distribution of NFB and the clusters formation of AMF in the sample collection point (Figures 4 and 5).

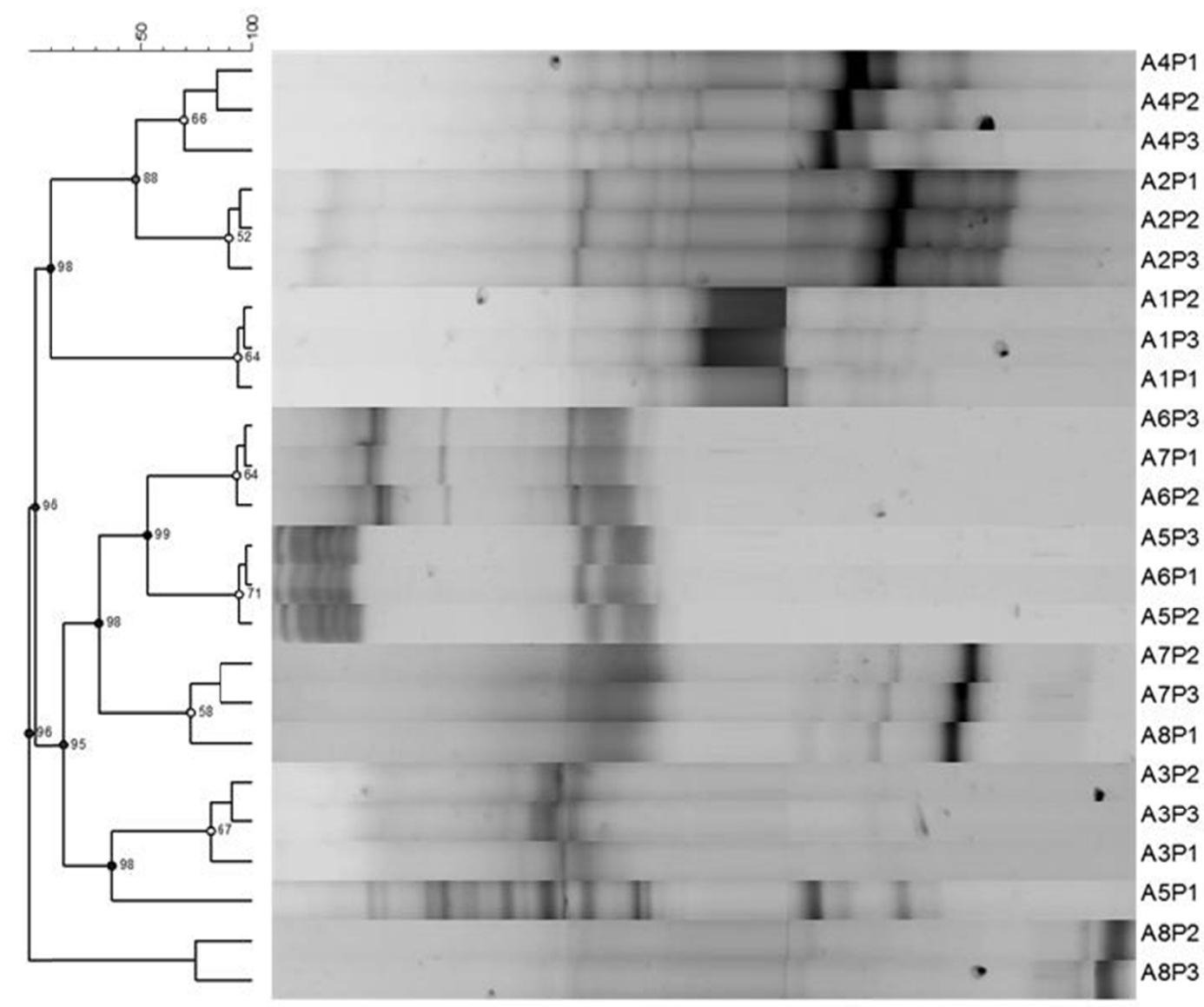

Figure 5. UPGMA dendogram and DGGE profile of $18 S$ rDNA gene from Cerrado soil before the use of biofertigation with wastewater/manure from cattle slaughterhouse. A1P1: sample collection point 1 and soil depth $1(0-10 \mathrm{~cm})$, A1P2: sample collection point 1 and soil depth $2(10-20 \mathrm{~cm})$, A1P3: sample collection point 1 and soil depth $3(20-30 \mathrm{~cm}), \mathrm{A} 2$ : sample collection point 2 and so on until A8

We observed 50\% similarity between the microbial groups present at the sample collection points A1, A2 and A4 (Figures 4 and 5). While in the other points, the clusters were formed in function of soil depth. Thus, the microbial diversity in the soil portion of the blocks 1 and 2 was lower than in the soil portion of the blocks 3 and 4 (Figures 1, 4 and 5). In addition, it observed a high similarity between the microorganisms present at the same soil depth.

Different from the viable cell count, the DGGE profile showed the presence of AMF at depths of 20 to $30 \mathrm{~cm}$ (P3). This fact can be due to the many of the AMFs are biotrophic (Folli-Pereira et al., 2012). It also confirms the greatest sensitivity of the DGGE in relation to viable cell counts, as shown by other authors (Liang et al., 2008, van Elsas \& Boersma, 2011).

\subsection{Analyzes Carried out After Biofertigation Management}

\subsubsection{Water Management and Evaluation Physical-Chemical of Irrigation Water}

Water management began with the application of a water layer of $43.1 \mathrm{~mm}$. This volume was calculated by available soil water capacity (ASW) at the effective depth of the roots and the water retention in the soil (Table 4). After this first water management, we did another 63 with the irrigation schedule of 3 and 4 days (Table 4). This irrigation schedule was calculated by the ratio of actual soil water capacity (ASWC) and the daily potential 
evapotranspiration (Table 4). The ASWC represented about $50 \%$ of the ASW that is the maximum limit of water in the soil to avoid the water stress of the plant.

During the biofertigation management, an excess of water in the soil was observed (Table 4). This fact was due to precipitations with intensity higher than the ASW. This excess water caused the leaching of fine soil particles (silt and clay) and nutrients. Furthermore, the mean water demand of Brachiaria brizantha calculated by the ratio between the maximum crop evapotranspiration and the time of biofertigation management was $4.1 \mathrm{~mm} / \mathrm{d}$ (Table 4).

Table 4. Water and climatic parameters measured during the biofertigation of Brachiaria brizantha cv. Marandu in Palmas, TO, Brazil from 06/22/2015 to 03/27/2016

\begin{tabular}{lll}
\hline Water and climatic parameters & Amount & Unit \\
\hline Available water capacity in soil (ASW) & 51.6 & $\mathrm{~mm}$ \\
Soil water retention & 8.5 & $\mathrm{~mm}$ \\
Actual soil water capacity (ASWC) & 25.8 & $\mathrm{~mm}$ \\
Daily potential evapotranspiration & 4.7 & $\mathrm{~mm}$ \\
Maximum crop evapotranspiration & 1.145 .9 & $\mathrm{~mm}$ \\
Precipitation occurred during crop management & 915.3 & $\mathrm{~mm}$ \\
Water blade applied without or with the management of biofertigation & 792.6 & $\mathrm{~mm}$ \\
Excessive water during management of biofertigation & 562.0 & $\mathrm{~mm}$ \\
During of the management of biofertigation & 279 & $\mathrm{dia}$ \\
\hline
\end{tabular}

\subsubsection{Characterization of Physical-Chemical Indicators of Soil}

The physical-chemical indicators did not present significant differences in their contents along the soil depth, in all biofertigation management (Table 5). These indicators in the soil solution presented a greater dispersion with the biofertigation than dispersion before the preparation of the soil for the planting. According to Koura et al. (2002), it requires several years of irrigation with wastewater to achieve changes in physical-chemical characteristics. However, we results show o potential of use of wastewater/manure of green line as nutrient source and water by $B$. brizantha cv Marandu that is important for cattle food.

\subsubsection{Characterization of Leaf Biomass}

In the first cut, leaf biomass productivity was low. This result may be due to the initial stages of plant growth or interference of wastewater/manure in the formation of foliar mass (Figure 6A). However, leaf biomass productivity did not show a significant difference $(\mathrm{p}<0.05)$ between the treatments without or with the use of wastewater/manure (Figure 6A). Therefore, the low productivity, regardless of the management, was due to the culture not having completed the development, at this stage.

The second cut of the leaf mass was performed at 209 days of planting and at 49 days after the first cut (Figure $6 \mathrm{~B}$ ). The organic and mineral masses were larger in this cut than in the other cuts (Figure 6). Thus, the ideal period for cutting the leaf mass, regardless of the use of biofertigation, was after 200 days of forage planting.

Leaf biomass productivity in the second cut had significant differences $(p<0.05)$ between the biofertigation managements (Figure 6B).

Similar to that observed in the first cut, the leaf biomass productivity in the second cut was greater in managements with manure than other (Figure 6). In addition, the leaf biomass productivity in the biofertigation managements was higher than in the managements without the use wastewater/manure. These results show that, at this stage of plant growth, the use of the biofertigation has a positive effect on the growth and production of $B$. brizantha cv. Marandu in the Cerrado soil.

The third cut was performed at 280 days of planting and at 71 days after the second cut (Figure 6C). In this last cut, we observed, respectively, a reduction of leaf biomass productivity in managements with manure and an increase of this productivity in the other managements in relation to the second cut (Figure 6). This shows the forage regrowth capacity. Silva (2017) also shows this B. brizantha ability in Cerrado soil in fertigation management. Thus, the regrowth may be related to the use of wastewater in the irrigation of this forage. 
Table 5. Physical-chemical indicators concentration after of the planting Brachiaria brizantha cv Marandu and biofertigation management (M1 at M10) with wastewater/manure of the green line

\begin{tabular}{|c|c|c|c|c|c|c|c|c|}
\hline \multirow{3}{*}{$\begin{array}{l}\text { Biofertigation } \\
\text { management }\end{array}$} & \multirow{3}{*}{\multicolumn{2}{|c|}{ Physical-chemical indicators }} & \multicolumn{6}{|c|}{ Soil detph $(\mathrm{cm})$} \\
\hline & & & \multicolumn{2}{|c|}{$0-10$} & \multicolumn{2}{|c|}{$10-20$} & \multicolumn{2}{|c|}{$20-30$} \\
\hline & & & Average \pm Sd & $\mathrm{CV}$ & Average $\pm \mathrm{Sd}$ & $\mathrm{CV}$ & Average \pm Sd & $\mathrm{CV}$ \\
\hline \multirow{21}{*}{ M1 } & $\mathrm{pH}\left(\mathrm{CaCl}_{2}\right)$ & & $4.73 \pm 0.35 \mathrm{a}$ & 4.7 & $4.53 \pm 0.20 \mathrm{a}$ & 2.8 & $4.43 \pm 0.24 \mathrm{a}$ & 3.4 \\
\hline & Clay & \multirow{3}{*}{$\%$} & $26.00 \pm 6.09 \mathrm{a}$ & 14.7 & $30.50 \pm 7.52 \mathrm{a}$ & 15.5 & $36.00 \pm 7.46 \mathrm{a}$ & 13.0 \\
\hline & Sand & & $50.75 \pm 12.00 \mathrm{a}$ & 14.9 & $48.75 \pm 15.12 \mathrm{a}$ & 19.5 & $39.00 \pm 11.84 \mathrm{a}$ & 19.1 \\
\hline & Limo & & $23.25 \pm 6.15 \mathrm{a}$ & 16.6 & $20.75 \pm 7.62 \mathrm{a}$ & 23.1 & $25.00 \pm 5.03 \mathrm{a}$ & 12.6 \\
\hline & $\mathrm{Ca}$ & \multirow{6}{*}{$\mathrm{cmolc} / \mathrm{dm}^{3}$} & $1.60 \pm 0.87 \mathrm{a}$ & 34.2 & $0.85 \pm 0.59 \mathrm{a}$ & 43.5 & $0.58 \pm 0.46 \mathrm{a}$ & 50.0 \\
\hline & $\mathrm{Mg}$ & & $0.85 \pm 0.42 \mathrm{a}$ & 31.1 & $0.43 \pm 0.27 \mathrm{a}$ & 40.2 & $0.28 \pm 0.24 \mathrm{a}$ & 54.5 \\
\hline & $\mathrm{Al}$ & & $0.10 \pm 0.23 \mathrm{a}$ & 141.4 & $0.10 \pm 0.00 \mathrm{a}$ & 0.0 & $0.10 \pm 0.23 \mathrm{a}$ & 141.4 \\
\hline & $\mathrm{H}+\mathrm{Al}$ & & $4.78 \pm 0.42 \mathrm{a}$ & 5.5 & $5.25 \pm 1.20 \mathrm{a}$ & 14.4 & $4.70 \pm 1.88 \mathrm{a}$ & 25.2 \\
\hline & $\mathrm{K}$ & & $0.05 \pm 0.03 \mathrm{a}$ & 32.9 & $0.03 \pm 0.01 \mathrm{a}$ & 21.6 & $0.03 \pm 0.01 \mathrm{a}$ & 16.1 \\
\hline & CEC & & $7.25 \pm 1.57 \mathrm{a}$ & 13.6 & $6.53 \pm 1.52 \mathrm{a}$ & 14.7 & $5.55 \pm 1.97 \mathrm{a}$ & 22.3 \\
\hline & Organic Matter & $\mathrm{g} / \mathrm{dm}^{3}$ & $25.25 \pm 7.62 \mathrm{a}$ & 19.0 & $25.25 \pm 7.62 \mathrm{a}$ & 19.0 & $22.25 \pm 2.39 \mathrm{a}$ & 6.7 \\
\hline & Base Saturation & \multirow{2}{*}{$\%$} & $33.73 \pm 11.35 \mathrm{a}$ & 21.1 & $19.80 \pm 11.31 \mathrm{a}$ & 35.9 & $16.15 \pm 11.09 \mathrm{a}$ & 43.1 \\
\hline & Al Saturation & & $4.03 \pm 7.57 \mathrm{a}$ & 118.2 & $8.18 \pm 6.21 \mathrm{a}$ & 47.7 & $11.50 \pm 24.41 \mathrm{a}$ & 133.4 \\
\hline & $\mathrm{Na}$ & \multirow{8}{*}{$\mathrm{mg} / \mathrm{dm}^{3}$} & $1.50 \pm 0.92 \mathrm{a}$ & 38.5 & $3.00 \pm 0.00 \mathrm{~b}$ & 0.0 & $1.50 \pm 0.92 \mathrm{a}$ & 38.5 \\
\hline & $\mathrm{Zn}$ & & $1.63 \pm 3.62 \mathrm{a}$ & 140.2 & $0.55 \pm 0.60 \mathrm{a}$ & 68.8 & $0.28 \pm 0.38 \mathrm{a}$ & 85.9 \\
\hline & $\mathrm{B}$ & & $0.18 \pm 0.15 \mathrm{a}$ & 54.7 & $0.15 \pm 0.09 \mathrm{a}$ & 38.5 & $0.13 \pm 0.08 \mathrm{a}$ & 40.0 \\
\hline & $\mathrm{Cu}$ & & $0.13 \pm 0.08 \mathrm{a}$ & 40.0 & $0.10 \pm 0.00 \mathrm{a}$ & 0.0 & $0.15 \pm 0.16 \mathrm{a}$ & 66.7 \\
\hline & $\mathrm{Fe}$ & & $36.75 \pm 10.42 \mathrm{a}$ & 17.8 & $28.75 \pm 11.35 \mathrm{a}$ & 24.8 & $23.00 \pm 10.15 \mathrm{a}$ & 27.7 \\
\hline & Mn & & $3.25 \pm 3.53 \mathrm{a}$ & 68.2 & $1.75 \pm 0.80 \mathrm{a}$ & 28.6 & $1.25 \pm 0.80 \mathrm{a}$ & 40.0 \\
\hline & $\mathrm{K}$ & & $19.00 \pm 9.89 \mathrm{a}$ & 32.7 & $13.50 \pm 4.77 \mathrm{a}$ & 22.2 & $11.50 \pm 3.05 \mathrm{a}$ & 16.7 \\
\hline & P (Melich I) & & $1.50 \pm 0.92 \mathrm{a}$ & 38.5 & $1.25 \pm 0.80 \mathrm{a}$ & 40.0 & $1.25 \pm 0.80 \mathrm{a}$ & 40.0 \\
\hline \multirow{21}{*}{ M2 } & $\mathrm{pH}\left(\mathrm{CaCl}_{2}\right)$ & & $4.58 \pm 0.56 \mathrm{a}$ & 7.7 & $4.48 \pm 0.57 \mathrm{a}$ & 8.0 & $4.48 \pm 0.46 \mathrm{a}$ & 6.4 \\
\hline & Clay & & $26.50 \pm 4.00 \mathrm{a}$ & 9.5 & $29.00 \pm 2.60 \mathrm{a}$ & 5.6 & $33.75 \pm 8.75 \mathrm{a}$ & 16.3 \\
\hline & Sand & $\%$ & $53.25 \pm 3.28 \mathrm{a}$ & 3.9 & $47.00 \pm 0.00 \mathrm{~b}$ & 0.0 & $43.75 \pm 9.76 \mathrm{ab}$ & 14.0 \\
\hline & Limo & & $20.25 \pm 0.80 \mathrm{a}$ & 2.5 & $24.00 \pm 2.60 \mathrm{~b}$ & 6.8 & $22.50 \pm 5.28 \mathrm{ab}$ & 14.7 \\
\hline & $\mathrm{Ca}$ & \multirow{6}{*}{$\mathrm{cmolc} / \mathrm{dm}^{3}$} & $1.38 \pm 1.33 \mathrm{a}$ & 61.0 & $0.85 \pm 0.72 \mathrm{a}$ & 53.0 & $0.65 \pm 0.69 \mathrm{a}$ & 67.1 \\
\hline & $\mathrm{Mg}$ & & $0.60 \pm 0.58 \mathrm{a}$ & 60.9 & $0.48 \pm 0.69 \mathrm{a}$ & 91.6 & $0.28 \pm 0.35 \mathrm{a}$ & 80.6 \\
\hline & $\mathrm{Al}$ & & $0.13 \pm 0.20 \mathrm{a}$ & 100.7 & $0.15 \pm 0.21 \mathrm{a}$ & 86.1 & $0.08 \pm 0.08 \mathrm{a}$ & 66.7 \\
\hline & $\mathrm{H}+\mathrm{Al}$ & & $5.10 \pm 3.37 \mathrm{a}$ & 41.5 & $4.90 \pm 3.21 \mathrm{a}$ & 41.1 & $4.40 \pm 2.65 \mathrm{a}$ & 37.9 \\
\hline & $\mathrm{K}$ & & $0.07 \pm 0.07 \mathrm{a}$ & 64.8 & $0.07 \pm 0.07 \mathrm{a}$ & 63.2 & $0.05 \pm 0.07 \mathrm{a}$ & 88.9 \\
\hline & CEC & & $7.13 \pm 1.64 \mathrm{a}$ & 14.5 & $6.30 \pm 1.97 \mathrm{a}$ & 19.6 & $5.35 \pm 1.70 \mathrm{a}$ & 19.9 \\
\hline & Organic Matter & $\mathrm{g} / \mathrm{dm}^{3}$ & $26.00 \pm 3.18 \mathrm{a}$ & 7.7 & $25.00 \pm 3.67 \mathrm{a}$ & 9.2 & $25.00 \pm 3.67 \mathrm{a}$ & 9.2 \\
\hline & Base Saturation & \multirow{2}{*}{$\%$} & $30.58 \pm 33.31 \mathrm{a}$ & 68.5 & $24.55 \pm 31.99 \mathrm{a}$ & 81.9 & $20.50 \pm 29.63 \mathrm{a}$ & 90.8 \\
\hline & Al Saturation & & $9.18 \pm 18.01 \mathrm{a}$ & 123.4 & $14.05 \pm 21.64 \mathrm{a}$ & 96.8 & $10.43 \pm 11.33 \mathrm{a}$ & 68.3 \\
\hline & $\mathrm{Na}$ & \multirow{8}{*}{$\mathrm{mg} / \mathrm{dm}^{3}$} & $1.50 \pm 0.92 \mathrm{a}$ & 38.5 & $2.25 \pm 0.80 \mathrm{a}$ & 22.2 & $1.50 \pm 1.59 \mathrm{a}$ & 66.7 \\
\hline & $\mathrm{Zn}$ & & $0.25 \pm 0.38 \mathrm{a}$ & 95.2 & $0.25 \pm 0.09 \mathrm{a}$ & 23.1 & $0.28 \pm 0.20 \mathrm{a}$ & 45.8 \\
\hline & $\mathrm{B}$ & & $0.18 \pm 0.15 \mathrm{a}$ & 54.7 & $0.20 \pm 0.18 \mathrm{a}$ & 57.7 & $0.15 \pm 0.09 \mathrm{a}$ & 38.5 \\
\hline & $\mathrm{Cu}$ & & $0.10 \pm 0.00 \mathrm{a}$ & 0.0 & $0.10 \pm 0.00$ & $0.0 \mathrm{a}$ & $0.13 \pm 0.08 \mathrm{a}$ & 40.0 \\
\hline & $\mathrm{Fe}$ & & $27.00 \pm 6.23 \mathrm{a}$ & 14.5 & $22.50 \pm 4.21 \mathrm{a}$ & 11.8 & $20.00 \pm 6.23 \mathrm{a}$ & 19.6 \\
\hline & $\mathrm{Mn}$ & & $2.00 \pm 2.25 \mathrm{a}$ & 70.7 & $1.75 \pm 2.39 \mathrm{a}$ & 85.7 & $1.75 \pm 2.39 \mathrm{a}$ & 85.7 \\
\hline & $\mathrm{K}$ & & $25.50 \pm 26.42 \mathrm{a}$ & 65.1 & $25.50 \pm 25.64 \mathrm{a}$ & 63.2 & $20.50 \pm 29.21 \mathrm{a}$ & 89.5 \\
\hline & P (Melich I) & & $1.75 \pm 1.52 \mathrm{a}$ & 54.7 & $1.75 \pm 1.52 \mathrm{a}$ & 54.7 & $1.50 \pm 0.92 \mathrm{a}$ & 38.5 \\
\hline
\end{tabular}


Table 5. Continued

\begin{tabular}{|c|c|c|c|c|c|c|c|c|}
\hline \multirow{3}{*}{$\begin{array}{l}\text { Biofertigation } \\
\text { management }\end{array}$} & \multirow{3}{*}{\multicolumn{2}{|c|}{ Physical-chemical indicators }} & \multicolumn{6}{|c|}{ Soil detph $(\mathrm{cm})$} \\
\hline & & & \multicolumn{2}{|l|}{$0-10$} & \multicolumn{2}{|c|}{$10-20$} & \multicolumn{2}{|c|}{$20-30$} \\
\hline & & & Average \pm Sd & $\mathrm{CV}$ & Average \pm Sd & $\mathrm{CV}$ & Average $\pm \mathrm{Sd}$ & $\mathrm{CV}$ \\
\hline \multirow{21}{*}{ M3 } & $\mathrm{pH}\left(\mathrm{CaCl}_{2}\right)$ & & $4.33 \pm 0.20 \mathrm{a}$ & 2.9 & $4.38 \pm 0.33 \mathrm{a}$ & 4.7 & $4.35 \pm 0.21 \mathrm{a}$ & 3.0 \\
\hline & Clay & & $31.75 \pm 11.28 \mathrm{a}$ & 22.3 & $32.25 \pm 10.66 \mathrm{a}$ & 20.8 & $35.25 \pm 5.57 \mathrm{a}$ & 9.9 \\
\hline & Sand & $\%$ & $46.75 \pm 12.07 \mathrm{a}$ & 16.2 & $43.75 \pm 9.76 \mathrm{a}$ & 14.0 & $40.00 \pm 7.35 \mathrm{a}$ & 11.5 \\
\hline & Limo & & $21.50 \pm 5.44 \mathrm{a}$ & 15.9 & $24.00 \pm 3.90 \mathrm{a}$ & 10.2 & $24.75 \pm 3.28 \mathrm{a}$ & 8.3 \\
\hline & $\mathrm{Ca}$ & \multirow{6}{*}{ cmolc $/ \mathrm{dm}^{3}$} & $0.65 \pm 0.40 \mathrm{a}$ & 38.7 & $0.58 \pm 0.56 \mathrm{a}$ & 60.9 & $0.43 \pm 0.08 \mathrm{a}$ & 11.8 \\
\hline & $\mathrm{Mg}$ & & $0.30 \pm 0.18 \mathrm{a}$ & 38.5 & $0.28 \pm 0.35 \mathrm{a}$ & 80.6 & $0.18 \pm 0.08 \mathrm{a}$ & 28.6 \\
\hline & $\mathrm{Al}$ & & $0.15 \pm 0.21 \mathrm{a}$ & 86.1 & $0.15 \pm 0.16 \mathrm{a}$ & 66.7 & $0.55 \pm 1.34 \mathrm{a}$ & 153.2 \\
\hline & $\mathrm{H}+\mathrm{Al}$ & & $4.73 \pm 3.11 \mathrm{a}$ & 41.4 & $4.85 \pm 2.27 \mathrm{a}$ & 29.4 & $4.35 \pm 2.79 \mathrm{a}$ & 40.4 \\
\hline & $\mathrm{K}$ & & $0.03 \pm 0.01 \mathrm{a}$ & 14.9 & $0.03 \pm 0.01 \mathrm{a}$ & 14.8 & $0.03 \pm 0.01 \mathrm{a}$ & 15.7 \\
\hline & $\mathrm{CEC}$ & & $5.68 \pm 3.25 \mathrm{a}$ & 36.0 & $5.70 \pm 2.31 \mathrm{a}$ & 25.5 & $4.95 \pm 2.90 \mathrm{a}$ & 36.8 \\
\hline & Organic Matter & $\mathrm{g} / \mathrm{dm}^{3}$ & $22.50 \pm 5.28 \mathrm{a}$ & 14.7 & $24.25 \pm 7.51 \mathrm{a}$ & 19.5 & $23.25 \pm 4.57 \mathrm{a}$ & 12.4 \\
\hline & Base Saturation & \multirow{2}{*}{$\%$} & $18.50 \pm 10.26 \mathrm{a}$ & 34.9 & $15.58 \pm 14.02 \mathrm{a}$ & 56.6 & $13.68 \pm 6.03 \mathrm{a}$ & 27.7 \\
\hline & Al Saturation & & $14.08 \pm 17.35 \mathrm{a}$ & 77.5 & $16.80 \pm 17.97 \mathrm{a}$ & 67.2 & $30.08 \pm 53.50 \mathrm{a}$ & 111.8 \\
\hline & $\mathrm{Na}$ & \multirow{8}{*}{$\mathrm{mg} / \mathrm{dm}^{3}$} & $2.75 \pm 0.80 \mathrm{a}$ & 18.2 & $1.75 \pm 0.80 \mathrm{a}$ & 28.6 & $1.75 \pm 0.80 \mathrm{a}$ & 28.6 \\
\hline & $\mathrm{Zn}$ & & $0.68 \pm 0.88 \mathrm{a}$ & 82.4 & $0.53 \pm 0.40 \mathrm{a}$ & 47.6 & $0.38 \pm 0.49 \mathrm{a}$ & 82.6 \\
\hline & $\mathrm{B}$ & & $0.18 \pm 0.15 \mathrm{a}$ & 54.7 & $0.13 \pm 0.08 \mathrm{a}$ & 40.0 & $0.25 \pm 0.09 \mathrm{a}$ & 23.1 \\
\hline & $\mathrm{Cu}$ & & $0.10 \pm 0.00 \mathrm{a}$ & 0.0 & $0.18 \pm 0.15 \mathrm{a}$ & 54.7 & $0.10 \pm 0.00 \mathrm{a}$ & 0.0 \\
\hline & $\mathrm{Fe}$ & & $25.75 \pm 11.72 \mathrm{a}$ & 28.6 & $22.75 \pm 8.85 \mathrm{a}$ & 24.4 & $18.00 \pm 7.46 \mathrm{a}$ & 26.1 \\
\hline & $\mathrm{Mn}$ & & $2.25 \pm 3.01 \mathrm{a}$ & 84.1 & $1.50 \pm 0.92 \mathrm{a}$ & 38.5 & $1.00 \pm 0.00 \mathrm{a}$ & 0.0 \\
\hline & $\mathrm{K}$ & & $13.00 \pm 3.18 \mathrm{a}$ & 15.4 & $12.50 \pm 3.05 \mathrm{a}$ & 15.3 & $10.00 \pm 2.60 \mathrm{a}$ & 16.3 \\
\hline & P (Melich I) & & $1.75 \pm 1.52 \mathrm{a}$ & 54.7 & $1.25 \pm 0.80 \mathrm{a}$ & 40.0 & $1.75 \pm 1.52 \mathrm{a}$ & 54.7 \\
\hline \multirow{21}{*}{ M4 } & $\mathrm{pH}\left(\mathrm{CaCl}_{2}\right)$ & & $4.70 \pm 0.57 \mathrm{a}$ & 7.6 & $4.45 \pm 0.28 \mathrm{a}$ & 3.9 & $4.33 \pm 0.08 \mathrm{a}$ & 1.2 \\
\hline & Clay & & $28.50 \pm 4.00 \mathrm{a}$ & 8.8 & $32.00 \pm 3.90 \mathrm{a}$ & 7.7 & $36.50 \pm 4.59 \mathrm{a}$ & 7.9 \\
\hline & Sand & $\%$ & $51.25 \pm 5.86 \mathrm{a}$ & 7.2 & $43.50 \pm 10.75 \mathrm{a}$ & 15.5 & $40.00 \pm 7.35 \mathrm{a}$ & 11.5 \\
\hline & Limo & & $20.25 \pm 2.00 \mathrm{a}$ & 6.2 & $24.50 \pm 7.06 \mathrm{a}$ & 18.1 & $23.50 \pm 2.76 \mathrm{a}$ & 7.4 \\
\hline & $\mathrm{Ca}$ & \multirow{6}{*}{$\mathrm{cmolc} / \mathrm{dm}^{3}$} & $1.58 \pm 1.44 \mathrm{a}$ & 57.3 & $0.80 \pm 0.54 \mathrm{a}$ & 42.1 & $0.48 \pm 0.08 \mathrm{a}$ & 10.5 \\
\hline & $\mathrm{Mg}$ & & $0.70 \pm 0.57 \mathrm{a}$ & 50.8 & $0.33 \pm 0.20 \mathrm{a}$ & 38.7 & $0.18 \pm 0.08 \mathrm{a}$ & 28.6 \\
\hline & $\mathrm{Al}$ & & $0.05 \pm 0.16 \mathrm{a}$ & 200.0 & $0.10 \pm 0.13 \mathrm{a}$ & 81.6 & $0.13 \pm 0.08 \mathrm{a}$ & 40.0 \\
\hline & $\mathrm{H}+\mathrm{Al}$ & & $4.60 \pm 2.45 \mathrm{a}$ & 33.5 & $5.43 \pm 1.57 \mathrm{a}$ & 18.1 & $5.25 \pm 0.94 \mathrm{a}$ & 11.3 \\
\hline & K & & $0.03 \pm 0.02 \mathrm{ab}$ & 38.8 & $0.03 \pm 0.00 \mathrm{a}$ & 0.0 & $0.02 \pm 0.00 \mathrm{~b}$ & 10.1 \\
\hline & $\mathrm{CEC}$ & & $6.90 \pm 1.36 \mathrm{a}$ & 12.4 & $6.55 \pm 1.11 \mathrm{a}$ & 10.6 & $5.90 \pm 0.90 \mathrm{a}$ & 9.6 \\
\hline & Organic Matter & $\mathrm{g} / \mathrm{dm}^{3}$ & $23.00 \pm 0.00 \mathrm{a}$ & 0.0 & $25.00 \pm 6.37 \mathrm{ab}$ & 16.0 & $19.00 \pm 3.18 \mathrm{~b}$ & 10.5 \\
\hline & Base Saturation & \multirow{2}{*}{$\%$} & $34.00 \pm 27.61 \mathrm{a}$ & 51.0 & $17.90 \pm 11.74 \mathrm{a}$ & 41.2 & $11.53 \pm 2.66 \mathrm{a}$ & 14.5 \\
\hline & Al Saturation & & $5.88 \pm 18.70 \mathrm{a}$ & 200.0 & $9.30 \pm 16.59 \mathrm{a}$ & 112.1 & $15.35 \pm 6.76 \mathrm{a}$ & 27.7 \\
\hline & $\mathrm{Na}$ & \multirow{8}{*}{$\mathrm{mg} / \mathrm{dm}^{3}$} & $1.75 \pm 1.52 \mathrm{a}$ & 54.7 & $2.75 \pm 0.80 \mathrm{a}$ & 18.2 & $1.75 \pm 1.52 \mathrm{a}$ & 54.7 \\
\hline & $\mathrm{Zn}$ & & $0.60 \pm 0.66 \mathrm{a}$ & 69.4 & $0.40 \pm 0.65 \mathrm{a}$ & 102.1 & $0.28 \pm 0.46 \mathrm{a}$ & 104.4 \\
\hline & $\mathrm{B}$ & & $0.20 \pm 0.18 \mathrm{a}$ & 57.7 & $0.20 \pm 0.13 \mathrm{a}$ & 40.8 & $0.18 \pm 0.15 \mathrm{a}$ & 54.7 \\
\hline & $\mathrm{Cu}$ & & $0.10 \pm 0.00 \mathrm{a}$ & 0.0 & $0.13 \pm 0.08 \mathrm{a}$ & 40.0 & $0.38 \pm 0.88 \mathrm{a}$ & 146.7 \\
\hline & $\mathrm{Fe}$ & & $30.50 \pm 11.36 \mathrm{a}$ & 23.4 & $30.25 \pm 10.18 \mathrm{a}$ & 21.1 & $21.75 \pm 4.57 \mathrm{a}$ & 13.2 \\
\hline & $\mathrm{Mn}$ & & $2.25 \pm 1.52 \mathrm{a}$ & 42.6 & $1.75 \pm 1.52 \mathrm{a}$ & 54.7 & $1.75 \pm 1.52 \mathrm{a}$ & 54.7 \\
\hline & $\mathrm{K}$ & & $12.50 \pm 7.96 \mathrm{a}$ & 40.0 & $10.00 \pm 0.00 \mathrm{a}$ & 0.0 & $9.50 \pm 1.59 \mathrm{a}$ & 10.5 \\
\hline & P (Melich I) & & $2.00 \pm 2.25 \mathrm{a}$ & 70.7 & $1.50 \pm 0.92 \mathrm{a}$ & 38.5 & $1.00 \pm 0.00 \mathrm{a}$ & 0.0 \\
\hline
\end{tabular}


Table 5. Continued

\begin{tabular}{|c|c|c|c|c|c|c|c|c|}
\hline \multirow{3}{*}{$\begin{array}{l}\text { Biofertigation } \\
\text { management }\end{array}$} & \multirow{3}{*}{\multicolumn{2}{|c|}{ Physical-chemical indicators }} & \multicolumn{6}{|c|}{ Soil detph $(\mathrm{cm})$} \\
\hline & & & \multicolumn{2}{|l|}{$0-10$} & \multicolumn{2}{|c|}{$10-20$} & \multicolumn{2}{|c|}{$20-30$} \\
\hline & & & Average \pm Sd & $\mathrm{CV}$ & Average $\pm \mathrm{Sd}$ & $\mathrm{CV}$ & Average \pm Sd & $\mathrm{CV}$ \\
\hline \multirow{21}{*}{ M5 } & $\mathrm{pH}\left(\mathrm{CaCl}_{2}\right)$ & & $4.33 \pm 0.35 \mathrm{a}$ & 5.1 & $4.43 \pm 0.42 \mathrm{a}$ & 5.9 & $4.38 \pm 0.33 \mathrm{a}$ & 4.7 \\
\hline & Clay & & $30.00 \pm 16.12 \mathrm{a}$ & 33.8 & $27.75 \pm 11.13 \mathrm{a}$ & 25.2 & $29.75 \pm 11.28 \mathrm{a}$ & 23.8 \\
\hline & Sand & $\%$ & $49.00 \pm 18.42 \mathrm{a}$ & 23.6 & $49.50 \pm 15.07 \mathrm{a}$ & 19.1 & $46.25 \pm 14.49 \mathrm{a}$ & 19.7 \\
\hline & Limo & & $21.00 \pm 2.91 \mathrm{a}$ & 8.7 & $22.75 \pm 4.75 \mathrm{a}$ & 13.1 & $24.00 \pm 3.90 \mathrm{a}$ & 10.2 \\
\hline & $\mathrm{Ca}$ & \multirow{6}{*}{$\mathrm{cmolc} / \mathrm{dm}^{3}$} & $0.70 \pm 0.75 \mathrm{a}$ & 67.0 & $0.75 \pm 0.64 \mathrm{a}$ & 53.9 & $0.60 \pm 0.45 \mathrm{a}$ & 47.1 \\
\hline & $\mathrm{Mg}$ & & $0.30 \pm 0.32 \mathrm{a}$ & 66.7 & $0.33 \pm 0.30 \mathrm{a}$ & 58.2 & $0.25 \pm 0.16 \mathrm{a}$ & 40.0 \\
\hline & $\mathrm{Al}$ & & $0.23 \pm 0.35 \mathrm{a}$ & 98.5 & $0.23 \pm 0.35 \mathrm{a}$ & 98.5 & $0.15 \pm 0.21 \mathrm{a}$ & 86.1 \\
\hline & $\mathrm{H}+\mathrm{Al}$ & & $5.58 \pm 3.11 \mathrm{a}$ & 35.1 & $4.43 \pm 2.15 \mathrm{a}$ & 30.5 & $4.33 \pm 2.04 \mathrm{a}$ & 29.6 \\
\hline & $\mathrm{K}$ & & $0.03 \pm 0.01 \mathrm{a}$ & 28.7 & $0.03 \pm 0.02 \mathrm{a}$ & 38.8 & $0.03 \pm 0.01 \mathrm{a}$ & 19.5 \\
\hline & CEC & & $6.58 \pm 2.65 \mathrm{a}$ & 25.3 & $5.53 \pm 1.89 \mathrm{a}$ & 21.5 & $5.18 \pm 1.96 \mathrm{a}$ & 23.8 \\
\hline & Organic Matter & $\mathrm{g} / \mathrm{dm}^{3}$ & $27.25 \pm 13.02 \mathrm{a}$ & 30.0 & $26.25 \pm 7.28 \mathrm{a}$ & 17.4 & $25.00 \pm 6.37 \mathrm{a}$ & 16.0 \\
\hline & Base Saturation & \multirow{2}{*}{$\%$} & $16.78 \pm 18.93 \mathrm{a}$ & 70.9 & $21.03 \pm 18.60 \mathrm{a}$ & 55.6 & $17.65 \pm 9.92 \mathrm{a}$ & 35.3 \\
\hline & Al Saturation & & $19.48 \pm 33.20 \mathrm{a}$ & 107.1 & $20.63 \pm 33.20 \mathrm{a}$ & 101.1 & $14.93 \pm 21.03 \mathrm{a}$ & 88.6 \\
\hline & $\mathrm{Na}$ & \multirow{8}{*}{$\mathrm{mg} / \mathrm{dm}^{3}$} & $1.75 \pm 1.52 \mathrm{a}$ & 54.7 & $2.25 \pm 0.80 \mathrm{a}$ & 22.2 & $2.00 \pm 1.30 \mathrm{a}$ & 40.8 \\
\hline & $\mathrm{Zn}$ & & $0.50 \pm 0.13 \mathrm{a}$ & 16.3 & $0.33 \pm 0.51 \mathrm{a}$ & 98.5 & $0.48 \pm 0.57 \mathrm{a}$ & 75.7 \\
\hline & B & & $0.20 \pm 0.13 \mathrm{a}$ & 40.8 & $0.23 \pm 0.15 \mathrm{a}$ & 42.6 & $0.18 \pm 0.08 \mathrm{a}$ & 28.6 \\
\hline & $\mathrm{Cu}$ & & $0.13 \pm 0.08 \mathrm{a}$ & 40.0 & $0.10 \pm 0.00 \mathrm{a}$ & 0.0 & $0.40 \pm 0.95 \mathrm{a}$ & 150.0 \\
\hline & $\mathrm{Fe}$ & & $26.25 \pm 12.69 \mathrm{a}$ & 30.4 & $25.75 \pm 8.15 \mathrm{a}$ & 19.9 & $21.50 \pm 6.43 \mathrm{a}$ & 18.8 \\
\hline & $\mathrm{Mn}$ & & $1.75 \pm 1.52 \mathrm{a}$ & 54.7 & $1.75 \pm 1.52 \mathrm{a}$ & 54.7 & $1.50 \pm 0.92 \mathrm{a}$ & 38.5 \\
\hline & $\mathrm{K}$ & & $11.50 \pm 5.44 \mathrm{a}$ & 29.7 & $12.50 \pm 7.96 \mathrm{a}$ & 40.0 & $12.50 \pm 4.00 \mathrm{a}$ & 20.1 \\
\hline & P (Melich I) & & $1.75 \pm 2.39 \mathrm{a}$ & 85.7 & $2.00 \pm 2.25 \mathrm{a}$ & 70.7 & $1.75 \pm 0.80 \mathrm{a}$ & 28.6 \\
\hline \multirow{21}{*}{ M6 } & $\mathrm{pH}\left(\mathrm{CaCl}_{2}\right)$ & & $4.58 \pm 0.46 \mathrm{a}$ & 6.3 & $4.40 \pm 0.23 \mathrm{a}$ & 3.2 & $4.40 \pm 0.13 \mathrm{a}$ & 1.9 \\
\hline & Clay & & $26.50 \pm 9.94 \mathrm{a}$ & 23.6 & $27.50 \pm 5.44 \mathrm{a}$ & 12.4 & $33.75 \pm 11.72 \mathrm{a}$ & 21.8 \\
\hline & Sand & $\%$ & $50.25 \pm 17.64 \mathrm{a}$ & 22.1 & $51.50 \pm 9.23 \mathrm{a}$ & 11.3 & $42.75 \pm 17.30 \mathrm{a}$ & 25.4 \\
\hline & Limo & & $23.25 \pm 7.94 \mathrm{a}$ & 21.5 & $21.00 \pm 4.31 \mathrm{a}$ & 12.9 & $23.50 \pm 5.88 \mathrm{a}$ & 15.7 \\
\hline & $\mathrm{Ca}$ & \multirow{6}{*}{$\mathrm{cmolc} / \mathrm{dm}^{3}$} & $0.90 \pm 0.62 \mathrm{a}$ & 43.5 & $0.58 \pm 0.35 \mathrm{a}$ & 38.6 & $0.53 \pm 0.40 \mathrm{a}$ & 47.6 \\
\hline & $\mathrm{Mg}$ & & $0.48 \pm 0.48 \mathrm{a}$ & 62.9 & $0.23 \pm 0.20 \mathrm{a}$ & 55.9 & $0.25 \pm 0.28 \mathrm{a}$ & 69.3 \\
\hline & $\mathrm{Al}$ & & $0.08 \pm 0.15 \mathrm{a}$ & 127.7 & $0.15 \pm 0.16 \mathrm{a}$ & 66.7 & $0.15 \pm 0.16 \mathrm{a}$ & 66.7 \\
\hline & $\mathrm{H}+\mathrm{Al}$ & & $4.03 \pm 2.57 \mathrm{a}$ & 40.1 & $4.35 \pm 2.79 \mathrm{a}$ & 40.4 & $4.13 \pm 1.45 \mathrm{a}$ & 22.2 \\
\hline & $\mathrm{K}$ & & $0.14 \pm 0.34 \mathrm{a}$ & 152.5 & $0.03 \pm 0.01 \mathrm{a}$ & 18.6 & $0.03 \pm 0.01 \mathrm{a}$ & 17.6 \\
\hline & $\mathrm{CEC}$ & & $5.53 \pm 2.29 \mathrm{a}$ & 26.0 & $5.15 \pm 2.59 \mathrm{a}$ & 31.6 & $4.90 \pm 1.50 \mathrm{a}$ & 19.2 \\
\hline & Organic Matter & $\mathrm{g} / \mathrm{dm}^{3}$ & $23.00 \pm 0.00 \mathrm{a}$ & 0.0 & $23.25 \pm 4.57 \mathrm{a}$ & 12.4 & $19.75 \pm 4.57 \mathrm{a}$ & 14.5 \\
\hline & Base Saturation & \multirow{2}{*}{$\%$} & $29.13 \pm 19.35 \mathrm{a}$ & 41.7 & $17.88 \pm 14.40 \mathrm{a}$ & 50.6 & $16.50 \pm 11.99 \mathrm{a}$ & 45.7 \\
\hline & Al Saturation & & $5.50 \pm 11.94 \mathrm{a}$ & 136.5 & $17.48 \pm 24.88 \mathrm{a}$ & 89.5 & $15.23 \pm 2.82 \mathrm{a}$ & 11.6 \\
\hline & $\mathrm{Na}$ & \multirow{8}{*}{$\mathrm{mg} / \mathrm{dm}^{3}$} & $1.75 \pm 1.52 \mathrm{a}$ & 54.7 & $1.50 \pm 0.92 \mathrm{a}$ & 38.5 & $2.00 \pm 1.30 \mathrm{a}$ & 40.8 \\
\hline & $\mathrm{Zn}$ & & $0.43 \pm 1.03 \mathrm{a}$ & 152.9 & $0.53 \pm 0.69 \mathrm{a}$ & 82.8 & $0.43 \pm 0.61 \mathrm{a}$ & 90.9 \\
\hline & B & & $0.15 \pm 0.09 \mathrm{a}$ & 38.5 & $0.18 \pm 0.15 \mathrm{a}$ & 54.7 & $0.23 \pm 0.15 \mathrm{a}$ & 42.6 \\
\hline & $\mathrm{Cu}$ & & $0.10 \pm 0.00 \mathrm{a}$ & 0.0 & $0.10 \pm 0.00 \mathrm{a}$ & 0.0 & $0.10 \pm 0.00 \mathrm{a}$ & 0.0 \\
\hline & $\mathrm{Fe}$ & & $25.50 \pm 8.37 \mathrm{a}$ & 20.6 & $23.25 \pm 4.57 \mathrm{a}$ & 12.4 & $20.00 \pm 2.60 \mathrm{a}$ & 8.2 \\
\hline & $\mathrm{Mn}$ & & $2.00 \pm 1.30 \mathrm{a}$ & 40.8 & $1.25 \pm 0.80 \mathrm{a}$ & 40.0 & $1.25 \pm 0.80 \mathrm{a}$ & 40.0 \\
\hline & $\mathrm{K}$ & & $54.75 \pm 132.95 \mathrm{a}$ & 152.6 & $12.00 \pm 3.67 \mathrm{a}$ & 19.2 & $10.50 \pm 3.05 \mathrm{a}$ & 18.2 \\
\hline & P (Melich I) & & $2.25 \pm 2.00 \mathrm{a}$ & 55.9 & $1.75 \pm 0.80 \mathrm{a}$ & 28.6 & $1.75 \pm 1.52 \mathrm{a}$ & 54.7 \\
\hline
\end{tabular}


Table 5. Continued

\begin{tabular}{|c|c|c|c|c|c|c|c|c|}
\hline \multirow{3}{*}{$\begin{array}{l}\text { Biofertigation } \\
\text { management }\end{array}$} & \multirow{3}{*}{\multicolumn{2}{|c|}{ Physical-chemical indicators }} & \multicolumn{6}{|c|}{ Soil detph $(\mathrm{cm})$} \\
\hline & & & \multicolumn{2}{|l|}{$0-10$} & \multicolumn{2}{|c|}{$10-20$} & \multicolumn{2}{|c|}{$20-30$} \\
\hline & & & Average \pm Sd & $\mathrm{CV}$ & Average $\pm \mathrm{Sd}$ & $\mathrm{CV}$ & Average $\pm \mathrm{Sd}$ & $\mathrm{CV}$ \\
\hline \multirow{21}{*}{ M7 } & $\mathrm{pH}\left(\mathrm{CaCl}_{2}\right)$ & & $4.55 \pm 0.62 \mathrm{a}$ & 8.5 & $4.43 \pm 0.35 \mathrm{a}$ & 5.0 & $4.43 \pm 0.51 \mathrm{a}$ & 7.2 \\
\hline & Clay & & $27.50 \pm 10.52 \mathrm{a}$ & 24.0 & $27.75 \pm 7.28 \mathrm{a}$ & 16.5 & $30.25 \pm 13.08 \mathrm{a}$ & 27.2 \\
\hline & Sand & $\%$ & $52.25 \pm 9.04 \mathrm{a}$ & 10.9 & $49.50 \pm 13.28 \mathrm{a}$ & 16.9 & $48.50 \pm 15.07 \mathrm{a}$ & 19.5 \\
\hline & Limo & & $20.25 \pm 1.52 \mathrm{a}$ & 4.7 & $22.75 \pm 6.80 \mathrm{a}$ & 18.8 & $21.25 \pm 5.72 \mathrm{a}$ & 16.9 \\
\hline & $\mathrm{Ca}$ & \multirow{6}{*}{$\mathrm{cmolc} / \mathrm{dm}^{3}$} & $0.93 \pm 0.88 \mathrm{a}$ & 60.1 & $0.88 \pm 0.83 \mathrm{a}$ & 59.3 & $0.68 \pm 0.77 \mathrm{a}$ & 71.9 \\
\hline & $\mathrm{Mg}$ & & $0.45 \pm 0.42 \mathrm{a}$ & 58.8 & $0.35 \pm 0.28 \mathrm{a}$ & 49.5 & $0.33 \pm 0.51 \mathrm{a}$ & 98.5 \\
\hline & $\mathrm{Al}$ & & $0.13 \pm 0.20 \mathrm{a}$ & 100.7 & $0.20 \pm 0.29 \mathrm{a}$ & 91.3 & $0.13 \pm 0.20 \mathrm{a}$ & 100.7 \\
\hline & $\mathrm{H}+\mathrm{Al}$ & & $4.40 \pm 2.71 \mathrm{a}$ & 38.7 & $5.20 \pm 2.09 \mathrm{a}$ & 25.2 & $5.40 \pm 1.65 \mathrm{a}$ & 19.2 \\
\hline & $\mathrm{K}$ & & $0.03 \pm 0.01 \mathrm{a}$ & 24.6 & $0.03 \pm 0.01 \mathrm{a}$ & 28.7 & $0.03 \pm 0.01 \mathrm{a}$ & 22.6 \\
\hline & CEC & & $5.78 \pm 1.43 \mathrm{a}$ & 15.6 & $6.43 \pm 1.16 \mathrm{a}$ & 11.3 & $6.40 \pm 0.55 \mathrm{a}$ & 5.4 \\
\hline & Organic Matter & $\mathrm{g} / \mathrm{dm}^{3}$ & $25.25 \pm 10.59 \mathrm{a}$ & 26.3 & $25.00 \pm 3.67 \mathrm{a}$ & 9.2 & $27.25 \pm 9.76 \mathrm{a}$ & 22.5 \\
\hline & Base Saturation & \multirow{2}{*}{$\%$} & $26.58 \pm 30.95 \mathrm{a}$ & 73.2 & $20.30 \pm 19.74 \mathrm{a}$ & 61.1 & $16.40 \pm 21.54 \mathrm{a}$ & 82.6 \\
\hline & Al Saturation & & $11.78 \pm 21.97 \mathrm{a}$ & 117.2 & $18.50 \pm 29.55 \mathrm{a}$ & 100.4 & $15.00 \pm 21.16 \mathrm{a}$ & 88.7 \\
\hline & $\mathrm{Na}$ & \multirow{8}{*}{$\mathrm{mg} / \mathrm{dm}^{3}$} & $2.00 \pm 1.84 \mathrm{a}$ & 57.7 & $2.00 \pm 1.30 \mathrm{a}$ & 40.8 & $2.00 \pm 1.30 \mathrm{a}$ & 40.8 \\
\hline & $\mathrm{Zn}$ & & $0.40 \pm 0.41 \mathrm{a}$ & 64.5 & $0.43 \pm 0.54 \mathrm{a}$ & 80.1 & $0.43 \pm 0.35 \mathrm{a}$ & 52.2 \\
\hline & B & & $0.20 \pm 0.13 \mathrm{a}$ & 40.8 & $0.15 \pm 0.09 \mathrm{a}$ & 38.5 & $0.20 \pm 0.13 \mathrm{a}$ & 40.8 \\
\hline & $\mathrm{Cu}$ & & $0.10 \pm 0.00 \mathrm{a}$ & 0.0 & $0.13 \pm 0.08 \mathrm{a}$ & 40.0 & $0.10 \pm 0.00 \mathrm{a}$ & 0.0 \\
\hline & $\mathrm{Fe}$ & & $26.00 \pm 4.11 \mathrm{a}$ & 9.9 & $25.75 \pm 4.93 \mathrm{a}$ & 12.0 & $24.75 \pm 9.76 \mathrm{a}$ & 24.8 \\
\hline & $\mathrm{Mn}$ & & $1.75 \pm 1.52 \mathrm{a}$ & 54.7 & $2.00 \pm 1.30 \mathrm{a}$ & 40.8 & $1.75 \pm 1.52 \mathrm{a}$ & 54.7 \\
\hline & $\mathrm{K}$ & & $13.50 \pm 5.44 \mathrm{a}$ & 25.3 & $11.50 \pm 5.44 \mathrm{a}$ & 29.7 & $11.00 \pm 4.11 \mathrm{a}$ & 23.5 \\
\hline & P (Melich I) & & $2.25 \pm 1.52 \mathrm{a}$ & 42.6 & $2.00 \pm 1.30 \mathrm{a}$ & 40.8 & $1.75 \pm 0.80 \mathrm{a}$ & 28.6 \\
\hline \multirow{21}{*}{ M8 } & $\mathrm{pH}\left(\mathrm{CaCl}_{2}\right)$ & & $4.65 \pm 0.67 \mathrm{a}$ & 9.0 & $4.55 \pm 0.21 \mathrm{a}$ & 2.8 & $4.48 \pm 0.15 \mathrm{a}$ & 2.1 \\
\hline & Clay & & $23.25 \pm 3.76 \mathrm{a}$ & 10.2 & $26.75 \pm 8.26 \mathrm{ab}$ & 19.4 & $34.75 \pm 6.92 \mathrm{~b}$ & 12.5 \\
\hline & Sand & $\%$ & $57.50 \pm 3.05 \mathrm{a}$ & 3.3 & $51.25 \pm 16.61 \mathrm{ab}$ & 20.4 & $37.75 \pm 10.26 \mathrm{~b}$ & 17.1 \\
\hline & Limo & & $19.25 \pm 0.80 \mathrm{a}$ & 2.6 & $22.00 \pm 8.52 \mathrm{ab}$ & 24.3 & $27.50 \pm 4.21 \mathrm{~b}$ & 9.6 \\
\hline & $\mathrm{Ca}$ & \multirow{6}{*}{$\mathrm{cmolc} / \mathrm{dm}^{3}$} & $1.33 \pm 1.53 \mathrm{a}$ & 72.5 & $0.98 \pm 0.79 \mathrm{a}$ & 51.2 & $0.58 \pm 0.35 \mathrm{a}$ & 38.6 \\
\hline & $\mathrm{Mg}$ & & $0.70 \pm 0.76 \mathrm{a}$ & 68.0 & $0.48 \pm 0.35 \mathrm{a}$ & 46.7 & $0.28 \pm 0.08 \mathrm{a}$ & 18.2 \\
\hline & $\mathrm{Al}$ & & $0.10 \pm 0.23 \mathrm{a}$ & 141.4 & $0.10 \pm 0.00 \mathrm{a}$ & 0.0 & $0.08 \pm 0.08 \mathrm{a}$ & 66.7 \\
\hline & $\mathrm{H}+\mathrm{Al}$ & & $4.60 \pm 2.56 \mathrm{a}$ & 34.9 & $4.43 \pm 1.84 \mathrm{a}$ & 26.2 & $4.85 \pm 1.08 \mathrm{a}$ & 13.9 \\
\hline & $\mathrm{K}$ & & $0.04 \pm 0.02 \mathrm{a}$ & 37.6 & $0.03 \pm 0.01 \mathrm{a}$ & 23.3 & $0.04 \pm 0.02 \mathrm{a}$ & 34.0 \\
\hline & $\mathrm{CEC}$ & & $6.65 \pm 1.88 \mathrm{a}$ & 17.8 & $5.88 \pm 2.53 \mathrm{a}$ & 27.1 & $5.73 \pm 1.35 \mathrm{a}$ & 14.8 \\
\hline & Organic Matter & $\mathrm{g} / \mathrm{dm}^{3}$ & $25.25 \pm 7.62 \mathrm{a}$ & 19.0 & $22.25 \pm 7.28 \mathrm{a}$ & 20.6 & $23.25 \pm 4.57 \mathrm{a}$ & 12.4 \\
\hline & Base Saturation & \multirow{2}{*}{$\%$} & $30.80 \pm 30.16 \mathrm{a}$ & 61.5 & $24.60 \pm 12.01 \mathrm{a}$ & 30.7 & $15.33 \pm 4.89 \mathrm{a}$ & 20.1 \\
\hline & Al Saturation & & $10.05 \pm 24.17 \mathrm{a}$ & 151.1 & $7.53 \pm 5.79 \mathrm{a}$ & 48.3 & $8.00 \pm 9.45 \mathrm{a}$ & 74.2 \\
\hline & $\mathrm{Na}$ & \multirow{8}{*}{$\mathrm{mg} / \mathrm{dm}^{3}$} & $2.25 \pm 1.52 \mathrm{a}$ & 42.6 & $2.00 \pm 1.30 \mathrm{a}$ & 40.8 & $1.75 \pm 1.52 \mathrm{a}$ & 54.7 \\
\hline & $\mathrm{Zn}$ & & $0.55 \pm 1.03 \mathrm{a}$ & 117.4 & $0.58 \pm 0.91 \mathrm{a}$ & 99.8 & $0.43 \pm 0.75 \mathrm{a}$ & 111.0 \\
\hline & $\mathrm{B}$ & & $0.25 \pm 0.09 \mathrm{a}$ & 23.1 & $0.10 \pm 0.00 \mathrm{~b}$ & 0.0 & $0.25 \pm 0.09 \mathrm{a}$ & 23.1 \\
\hline & $\mathrm{Cu}$ & & $0.10 \pm 0.00 \mathrm{a}$ & 0.0 & $0.10 \pm 0.00 \mathrm{a}$ & 0.0 & $0.13 \pm 0.08 \mathrm{a}$ & 40.0 \\
\hline & $\mathrm{Fe}$ & & $30.75 \pm 4.57 \mathrm{a}$ & 9.3 & $24.75 \pm 14.20 \mathrm{a}$ & 36.0 & $19.00 \pm 11.98 \mathrm{a}$ & 39.6 \\
\hline & $\mathrm{Mn}$ & & $2.75 \pm 2.72 \mathrm{a}$ & 62.1 & $1.75 \pm 1.52 \mathrm{a}$ & 54.7 & $1.50 \pm 0.92 \mathrm{a}$ & 38.5 \\
\hline & $\mathrm{K}$ & & $15.50 \pm 9.50 \mathrm{a}$ & 38.5 & $12.50 \pm 4.77 \mathrm{a}$ & 24.0 & $14.00 \pm 7.80 \mathrm{a}$ & 35.0 \\
\hline & P (Melich I) & & $2.00 \pm 1.30 \mathrm{a}$ & 40.8 & $1.75 \pm 1.52 \mathrm{a}$ & 54.7 & $1.75 \pm 1.52 \mathrm{a}$ & 54.7 \\
\hline
\end{tabular}


Table 5. Continued

\begin{tabular}{|c|c|c|c|c|c|c|c|c|}
\hline \multirow{3}{*}{$\begin{array}{l}\text { Biofertigation } \\
\text { management }\end{array}$} & \multirow{3}{*}{\multicolumn{2}{|c|}{ Physical-chemical indicators }} & \multicolumn{6}{|c|}{ Soil detph $(\mathrm{cm})$} \\
\hline & & & \multicolumn{2}{|l|}{$0-10$} & \multicolumn{2}{|c|}{$10-20$} & \multicolumn{2}{|l|}{$20-30$} \\
\hline & & & Average \pm Sd & $\mathrm{CV}$ & Average \pm Sd & $\mathrm{CV}$ & Average \pm Sd & $\mathrm{CV}$ \\
\hline \multirow{21}{*}{ M9 } & $\mathrm{pH}\left(\mathrm{CaCl}_{2}\right)$ & & $4.90 \pm 1.11 \mathrm{a}$ & 14.2 & $4.73 \pm 1.16 \mathrm{a}$ & 15.4 & $4.63 \pm 0.73 \mathrm{a}$ & 9.9 \\
\hline & Clay & & $27.50 \pm 9.23 \mathrm{a}$ & 21.1 & $30.50 \pm 9.14 \mathrm{a}$ & 18.8 & $34.75 \pm 4.57 \mathrm{a}$ & 8.3 \\
\hline & Sand & $\%$ & $51.00 \pm 11.25 \mathrm{a}$ & 13.9 & $46.75 \pm 12.07 \mathrm{a}$ & 16.2 & $38.75 \pm 8.75 \mathrm{a}$ & 14.2 \\
\hline & Limo & & $21.50 \pm 3.05 \mathrm{a}$ & 8.9 & $22.75 \pm 5.09 \mathrm{a}$ & 14.1 & $26.50 \pm 5.28 \mathrm{a}$ & 12.5 \\
\hline & $\mathrm{Ca}$ & \multirow{6}{*}{$\mathrm{cmolc} / \mathrm{dm}^{3}$} & $1.73 \pm 2.67 \mathrm{a}$ & 97.2 & $1.28 \pm 2.40 \mathrm{a}$ & 118.1 & $0.83 \pm 1.35 \mathrm{a}$ & 103.0 \\
\hline & $\mathrm{Mg}$ & & $1.08 \pm 2.06 \mathrm{a}$ & 120.4 & $0.75 \pm 1.58 \mathrm{a}$ & 132.7 & $0.48 \pm 0.88 \mathrm{a}$ & 115.8 \\
\hline & $\mathrm{Al}$ & & $0.10 \pm 0.23 \mathrm{a}$ & 141.4 & $0.13 \pm 0.20 \mathrm{a}$ & 100.7 & $0.10 \pm 0.13 \mathrm{a}$ & 81.6 \\
\hline & $\mathrm{H}+\mathrm{Al}$ & & $3.80 \pm 2.22 \mathrm{a}$ & 36.7 & $3.20 \pm 1.50 \mathrm{a}$ & 29.4 & $3.60 \pm 1.85 \mathrm{a}$ & 32.2 \\
\hline & $\mathrm{K}$ & & $0.06 \pm 0.09 \mathrm{a}$ & 106.1 & $0.02 \pm 0.01 \mathrm{a}$ & 21.3 & $0.03 \pm 0.01 \mathrm{a}$ & 23.1 \\
\hline & CEC & & $6.63 \pm 2.71 \mathrm{a}$ & 25.7 & $5.23 \pm 4.10 \mathrm{a}$ & 49.3 & $4.90 \pm 2.81 \mathrm{a}$ & 36.0 \\
\hline & Organic Matter & $\mathrm{g} / \mathrm{dm}^{3}$ & $24.00 \pm 3.18 \mathrm{a}$ & 8.3 & $24.00 \pm 3.18 \mathrm{a}$ & 8.3 & $20.50 \pm 5.28 \mathrm{a}$ & 16.2 \\
\hline & Base Saturation & \multirow[b]{2}{*}{$\%$} & $37.83 \pm 45.79 \mathrm{a}$ & 76.1 & $31.00 \pm 39.18 \mathrm{a}$ & 79.4 & $24.58 \pm 27.82 \mathrm{a}$ & 71.1 \\
\hline & Al Saturation & & $8.00 \pm 19.79 \mathrm{a}$ & 155.5 & $15.38 \pm 25.41 \mathrm{a}$ & 103.8 & $12.93 \pm 15.80 \mathrm{a}$ & 76.8 \\
\hline & $\mathrm{Na}$ & \multirow{8}{*}{$\mathrm{mg} / \mathrm{dm}^{3}$} & $2.50 \pm 0.92 \mathrm{a}$ & 23.1 & $2.00 \pm 1.30 \mathrm{a}$ & 40.8 & $2.00 \pm 1.30 \mathrm{a}$ & 40.8 \\
\hline & $\mathrm{Zn}$ & & $0.58 \pm 0.60 \mathrm{a}$ & 65.7 & $0.48 \pm 0.42 \mathrm{a}$ & 55.4 & $0.48 \pm 0.57 \mathrm{a}$ & 75.7 \\
\hline & B & & $0.18 \pm 0.15 \mathrm{a}$ & 54.7 & $0.23 \pm 0.15 \mathrm{a}$ & 42.6 & $0.23 \pm 0.08 \mathrm{a}$ & 22.2 \\
\hline & $\mathrm{Cu}$ & & $0.10 \pm 0.00 \mathrm{a}$ & 0.0 & $0.13 \pm 0.08 \mathrm{a}$ & 40.0 & $0.10 \pm 0.00 \mathrm{a}$ & 0.0 \\
\hline & $\mathrm{Fe}$ & & $23.00 \pm 11.33 \mathrm{a}$ & 30.9 & $21.25 \pm 11.13 \mathrm{a}$ & 32.9 & $19.00 \pm 14.17 \mathrm{a}$ & 46.9 \\
\hline & $\mathrm{Mn}$ & & $2.00 \pm 1.30 \mathrm{a}$ & 40.8 & $2.00 \pm 2.25 \mathrm{a}$ & 70.7 & $1.75 \pm 2.39 \mathrm{a}$ & 85.7 \\
\hline & $\mathrm{K}$ & & $21.50 \pm 36.69 \mathrm{a}$ & 107.2 & $9.00 \pm 3.18 \mathrm{a}$ & 22.2 & $10.50 \pm 4.00 \mathrm{a}$ & 24.0 \\
\hline & P (Melich I) & & $2.00 \pm 1.30 \mathrm{a}$ & 40.8 & $2.00 \pm 1.84 \mathrm{a}$ & 57.7 & $2.25 \pm 1.52 \mathrm{a}$ & 42.6 \\
\hline \multirow{21}{*}{ M10 } & $\mathrm{pH}\left(\mathrm{CaCl}_{2}\right)$ & & $4.78 \pm 0.54 \mathrm{a}$ & 7.1 & $4.45 \pm 0.42 \mathrm{a}$ & 5.9 & $4.38 \pm 0.15 \mathrm{a}$ & 2.2 \\
\hline & Clay & & $23.75 \pm 6.01 \mathrm{a}$ & 15.9 & $28.50 \pm 4.77 \mathrm{ab}$ & 10.5 & $34.00 \pm 3.90 \mathrm{~b}$ & 7.2 \\
\hline & Sand & $\%$ & $54.25 \pm 3.98 \mathrm{a}$ & 4.6 & $49.25 \pm 7.16 \mathrm{a}$ & 9.1 & $36.00 \pm 0.00 \mathrm{~b}$ & 0.0 \\
\hline & Limo & & $22.00 \pm 4.50 \mathrm{a}$ & 12.9 & $22.25 \pm 3.28 \mathrm{a}$ & 9.3 & $30.00 \pm 3.90 \mathrm{~b}$ & 8.2 \\
\hline & $\mathrm{Ca}$ & \multirow{6}{*}{$\mathrm{cmolc} / \mathrm{dm}^{3}$} & $1.50 \pm 0.79 \mathrm{a}$ & 33.1 & $0.80 \pm 0.75 \mathrm{a}$ & 58.6 & $0.48 \pm 0.24 \mathrm{a}$ & 31.6 \\
\hline & $\mathrm{Mg}$ & & $0.65 \pm 0.54 \mathrm{a}$ & 52.5 & $0.30 \pm 0.23 \mathrm{a}$ & 47.1 & $0.28 \pm 0.24 \mathrm{a}$ & 54.5 \\
\hline & $\mathrm{Al}$ & & $0.08 \pm 0.15 \mathrm{a}$ & 127.7 & $0.18 \pm 0.15 \mathrm{a}$ & 54.7 & $0.10 \pm 0.00 \mathrm{a}$ & 0.0 \\
\hline & $\mathrm{H}+\mathrm{Al}$ & & $4.00 \pm 2.16 \mathrm{a}$ & 34.0 & $5.03 \pm 2.10 \mathrm{a}$ & 26.3 & $4.80 \pm 1.06 \mathrm{a}$ & 13.8 \\
\hline & $\mathrm{K}$ & & $0.04 \pm 0.01 \mathrm{a}$ & 21.5 & $0.04 \pm 0.01 \mathrm{a}$ & 20.1 & $0.06 \pm 0.07 \mathrm{a}$ & 70.9 \\
\hline & $\mathrm{CEC}$ & & $6.18 \pm 1.40 \mathrm{a}$ & 14.2 & $6.13 \pm 1.15 \mathrm{a}$ & 11.8 & $5.60 \pm 0.65 \mathrm{a}$ & 7.3 \\
\hline & Organic Matter & $\mathrm{g} / \mathrm{dm}^{3}$ & $27.00 \pm 0.00 \mathrm{a}$ & 0.0 & $23.25 \pm 4.57 \mathrm{a}$ & 12.4 & $21.50 \pm 7.41 \mathrm{a}$ & 21.6 \\
\hline & Base Saturation & \multirow{2}{*}{$\%$} & $36.63 \pm 25.99 \mathrm{a}$ & 44.6 & $19.68 \pm 20.09 \mathrm{a}$ & 64.2 & $14.75 \pm 10.17 \mathrm{a}$ & 43.3 \\
\hline & Al Saturation & & $4.40 \pm 8.81 \mathrm{a}$ & 125.9 & $16.90 \pm 21.13 \mathrm{a}$ & 78.6 & $11.65 \pm 4.53 \mathrm{a}$ & 24.5 \\
\hline & $\mathrm{Na}$ & \multirow{8}{*}{$\mathrm{mg} / \mathrm{dm}^{3}$} & $2.00 \pm 1.30 \mathrm{a}$ & 40.8 & $2.75 \pm 0.80 \mathrm{a}$ & 18.2 & $1.50 \pm 0.92 \mathrm{a}$ & 38.5 \\
\hline & $\mathrm{Zn}$ & & $0.73 \pm 0.85 \mathrm{a}$ & 73.3 & $0.60 \pm 0.85 \mathrm{a}$ & 89.2 & $0.55 \pm 0.87 \mathrm{a}$ & 99.0 \\
\hline & B & & $0.18 \pm 0.15 \mathrm{a}$ & 54.7 & $0.18 \pm 0.15 \mathrm{a}$ & 54.7 & $0.23 \pm 0.08 \mathrm{a}$ & 22.2 \\
\hline & $\mathrm{Cu}$ & & $0.13 \pm 0.08 \mathrm{a}$ & 40.0 & $0.10 \pm 0.00 \mathrm{a}$ & 0.0 & $0.50 \pm 1.17 \mathrm{a}$ & 147.0 \\
\hline & $\mathrm{Fe}$ & & $28.75 \pm 13.15 \mathrm{a}$ & 28.7 & $27.25 \pm 10.18 \mathrm{a}$ & 23.5 & $26.50 \pm 16.04 \mathrm{a}$ & 38.0 \\
\hline & $\mathrm{Mn}$ & & $2.00 \pm 1.30 \mathrm{a}$ & 40.8 & $1.50 \pm 0.92 \mathrm{a}$ & 38.5 & $7.75 \pm 21.48 \mathrm{a}$ & 174.2 \\
\hline & $\mathrm{K}$ & & $15.50 \pm 5.44 \mathrm{a}$ & 22.0 & $14.50 \pm 4.77 \mathrm{a}$ & 20.7 & $23.50 \pm 26.55 \mathrm{a}$ & 71.0 \\
\hline & P (Melich I) & & $2.25 \pm 0.80 \mathrm{a}$ & 22.2 & $2.00 \pm 1.30 \mathrm{a}$ & 40.8 & $2.25 \pm 0.80 \mathrm{a}$ & 22.2 \\
\hline
\end{tabular}

Note. Sd: standard deviation, CV: coefficient of variation (\%), CEC: cation exchange capacity. 

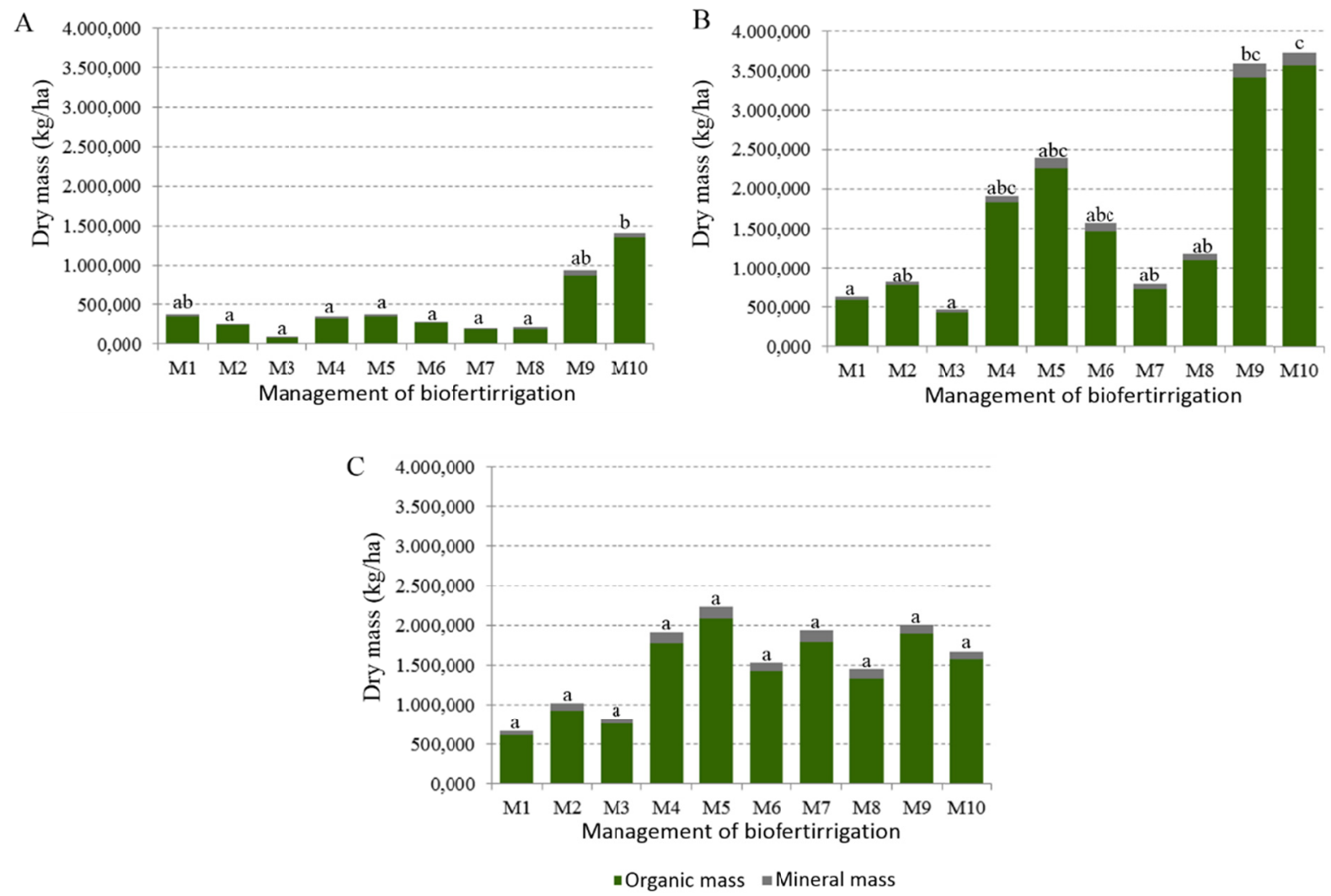

Figure 6. Leaf biomass productivity in the first (A), second (B) and third (C) cuts of Brachiaria brizantha cv. Marandu in biofertigation management (M1 to M10) with wastewater/manure from the green line of a cattle slaughterhouse. See the biofertigation management composition in Table 1

In the third cut, the leaf biomass productivity had a high coefficient of variation. Thus, we did not observe significant differences $(p<0.05)$ in leaf biomass productivity and in organic matter and mineral mass between managements (Figure 6). This high variability may be due to the excess water observed in the soil at this stage of the experiment (Table 4). The accumulation of this water content was due to the rains in the region.

Therefore, the wastewater/manure managements showed better plant growth than the managements without the use of biofertigation (M1 and M2). These results show the potential of using wastewater/manure from the green line of cattle slaughterhouse in the production of B. brizantha.

\subsubsection{Measurement of Viable Microorganisms in Soil}

After biofertigation, an increase in the number of viable microbial cells was observed, regardless of depth, when compared to the values obtained before forage planting (Tables 3 and 6). However, a reduction in the count of actinomycete and of fungi and an increase of bacterial cells were observed in the managements with wastewater/manure (Table 6). These changes in the number of viable microbial cells may be due to the physical-chemical characteristics of the effluents having altered the chemical composition of the soil.

Similar to that observed before soil preparation for planting, the count of viable microbial cells decreased as a function of soil depth and bacterial cell count was higher than that of fungi (Tables 3 and 6). In addition, in the managements without wastewater/manure, the viable fungal cells were observed in $20-30 \mathrm{~cm}$ that were not found before biofertigation (Tables 3 and 6). This result shows that the availability of nutrient and water allowed the germination of dormant cells and the nutrients of the wastewater from the green line did not have a significant infiltration in the soil to influence the biomass in the soil depths. 
Table 6. Counts of viable microbial cells in different soil depth after in the planting of Brachiaria brizantha cv Marandu and of the use of biofertigation management (M1 a M10) with cattle slaughterhouse wastewater/manure

\begin{tabular}{|c|c|c|c|c|}
\hline Biofertigation management & Soil detph & Actinomycete & Total Bacterias & Fungi \\
\hline \multirow{4}{*}{ M1 } & --------- cm ------- & |---------------. & $-\log \left(\mathrm{CFU} \mathrm{g}^{-1}\right)$ & ---------------------- \\
\hline & $0-10$ & $7.42 \pm 0.03$ & $8.52 \pm 0.09$ & $6.74 \pm 0.01$ \\
\hline & $10-20$ & $6.91 \pm 0.03$ & $8.36 \pm 0.07$ & $5.42 \pm 0.01$ \\
\hline & $20-30$ & $6.15 \pm 0.04$ & $7.25 \pm 0.04$ & $3.15 \pm 0.01$ \\
\hline \multirow{3}{*}{ M2 } & $0-10$ & $7.39 \pm 0.02$ & $8.25 \pm 0.02$ & $6.11 \pm 0.03$ \\
\hline & $10-20$ & $7.01 \pm 0.01$ & $7.74 \pm 0.07$ & $5.75 \pm 0.07$ \\
\hline & $20-30$ & $6.38 \pm 0.02$ & $7.08 \pm 0.01$ & $3.53 \pm 0.01$ \\
\hline \multirow{3}{*}{ M3 } & $0-10$ & $5.42 \pm 0.03$ & $11.19 \pm 0.09$ & $5.93 \pm 0.04$ \\
\hline & $10-20$ & $5.23 \pm 0.06$ & $10.89 \pm 0.05$ & $5.74 \pm 0.02$ \\
\hline & $20-30$ & $5.96 \pm 0.03$ & $8.26 \pm 0.06$ & $-^{\mathrm{a}}$ \\
\hline \multirow{3}{*}{ M4 } & $0-10$ & $4.78 \pm 0.01$ & $12.14 \pm 0.02$ & $6.14 \pm 0.04$ \\
\hline & $10-20$ & $4.37 \pm 0.03$ & $11.37 \pm 0.03$ & $5.94 \pm 0.03$ \\
\hline & $20-30$ & $5.55 \pm 0.07$ & $8.27 \pm 0.02$ & $-^{\mathrm{a}}$ \\
\hline \multirow{3}{*}{ M5 } & $0-10$ & $4.51 \pm 0.09$ & $12.85 \pm 0.03$ & $6.38 \pm 0.01$ \\
\hline & $10-20$ & $3.55 \pm 0.06$ & $12.05 \pm 0.03$ & $6.39 \pm 0.02$ \\
\hline & $20-30$ & $5.46 \pm 0.03$ & $8.26 \pm 0.02$ & $-^{\mathrm{a}}$ \\
\hline \multirow{3}{*}{ M6 } & $0-10$ & $3.24 \pm 0.09$ & $12.54 \pm 0.03$ & $5.43 \pm 0.01$ \\
\hline & $10-20$ & $2.31 \pm 0.06$ & $11.36 \pm 0.03$ & $5.09 \pm 0.02$ \\
\hline & $20-30$ & $5.04 \pm 0.03$ & $7.74 \pm 0.02$ & $-^{\mathrm{a}}$ \\
\hline \multirow{3}{*}{ M7 } & $0-10$ & $2.85 \pm 0.09$ & $14.11 \pm 0.03$ & $5.74 \pm 0.01$ \\
\hline & $10-20$ & $1.26 \pm 0.06$ & $13.13 \pm 0.03$ & $5.49 \pm 0.02$ \\
\hline & $20-30$ & $4.85 \pm 0.03$ & $7.86 \pm 0.02$ & $-^{\mathrm{a}}$ \\
\hline \multirow{3}{*}{ M8 } & $0-10$ & $2.78 \pm 0.09$ & $15.06 \pm 0.03$ & $6.21 \pm 0.01$ \\
\hline & $10-20$ & $1.61 \pm 0.06$ & $13.85 \pm 0.03$ & $5.87 \pm 0.02$ \\
\hline & $20-30$ & $5.32 \pm 0.03$ & $8.27 \pm 0.02$ & $-^{\mathrm{a}}$ \\
\hline \multirow{3}{*}{ M9 } & $0-10$ & $4.12 \pm 0.09$ & $13.01 \pm 0.03$ & $6.33 \pm 0.01$ \\
\hline & $10-20$ & $3.79 \pm 0.06$ & $12.40 \pm 0.03$ & $5.83 \pm 0.02$ \\
\hline & $20-30$ & $5.55 \pm 0.03$ & $8.01 \pm 0.02$ & $-^{\mathrm{a}}$ \\
\hline \multirow{3}{*}{ M10 } & $0-10$ & $3.57 \pm 0.09$ & $13.05 \pm 0.03$ & $6.54 \pm 0.01$ \\
\hline & $10-20$ & $3.21 \pm 0.06$ & $12.66 \pm 0.03$ & $6.17 \pm 0.02$ \\
\hline & $20-30$ & $5.64 \pm 0.03$ & $8.34 \pm 0.02$ & $-^{\mathrm{a}}$ \\
\hline
\end{tabular}

Note. a: values below 25 colonies. CFU: colony-forming unit. M1-M8: Biofertigation management (See the Table 1).

\subsubsection{Characterization of Microbial Diversity by DGGE Profile}

After the biofertigation managements, changes in the DGGE profile of the NFB and AMF communities were observed (Figures 4, 5, 7 and 8). We observed a decrease in the amount and an increase in the intensity of the bands which shows a reduction in species richness, but an increase in the in the pre-existing microbial community. These changes may be due to the difference in the sample collection period and the soil humidification. Due to the sensitivity the environmental and anthropogenic interferences, the NFB and AMF communities and the soil microbial activity are good indicators to soil quality (Barros et al., 2010).

Management without addition of fertilizer or wastewater/manure (M1) had greatest similarity in the profile of NFB bands with the M2 and M3 managements (Figure 7). The M7 and M8 with wastewater from the receiving box had the same band profile. These results demonstrate the influence of the chemical composition of the wastewater/manure on the NFB community (Figure 6). In addition, the changes on the NFB were due to the addition of NPK sources and dolomitic limestone. Biotic and abiotic factors, including soil acidity, affect the NFB community and decrease the symbiotic association efficiency between NFB and plants (Rufini et al., 2011). 
Therefore, the evaluation of the NFB community by DGGE showed to be a good parameter to study the changes caused by biofertigation in the Cerrado soil.

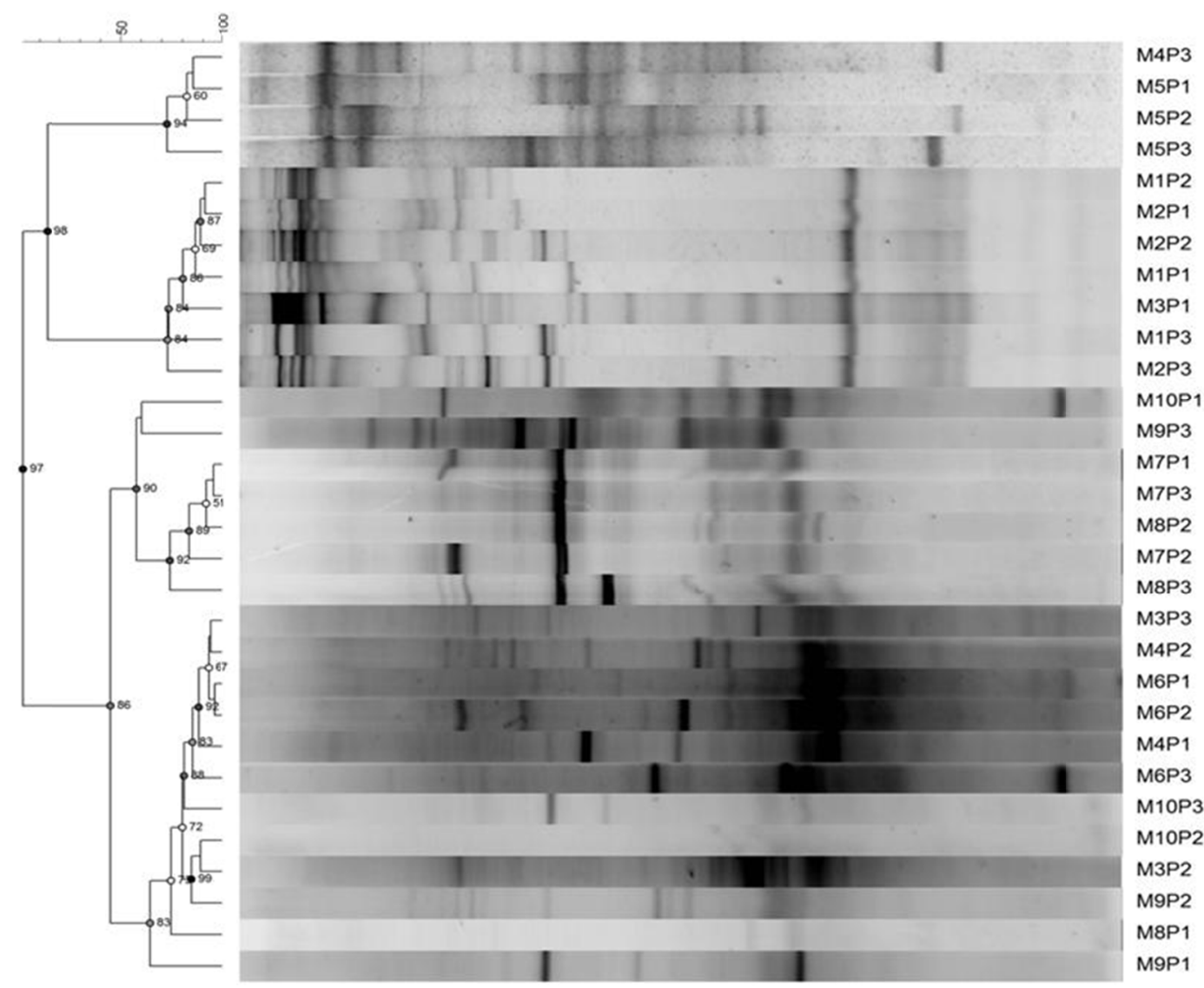

Figure 7. UPGMA dendogram and DGGE profile of $n i f H$ gene from Cerrado soil after the use of biofertigation (M1 at M10) with wastewater/manure from cattle slaughterhouse. P1: 0-10 cm, P2: 10-20 cm, P3: 20-30 cm of soil depth (See the Table 1)

The UPMG dendogram showed NFB clusters in function of soil depth and in different management (Figure 7). Thus, the biofertigation management in soil depths studied affected the NFB diversity. Clusters of nif $H$ gene by UPMG dendogram also were observed in a long term NPK fertilization (Tang et al., 2017).

The changes in band profiles of AMF community after the biofertigation management were observed at the soil surface (Figures 5 and 8). At other soil depths, the community of these microorganisms kept unchanged that may be due to the limitation of oxygen and nutrient in the deeper layers of the soil. The AMF are found mainly in the rhizosphere (Verma et al., 2008; Smith et al., 2010). Oxygen is one of the main factors that affects the microbial population. This element is used to classify the microorganisms in function of energy metabolism in aerobic, anaerobic and variations (Madigan et al., 2010; Moreira \& Siqueira, 2006). Thus, changes in AMF community was not due to biofertigation management, but soil depths with low oxygen level. 


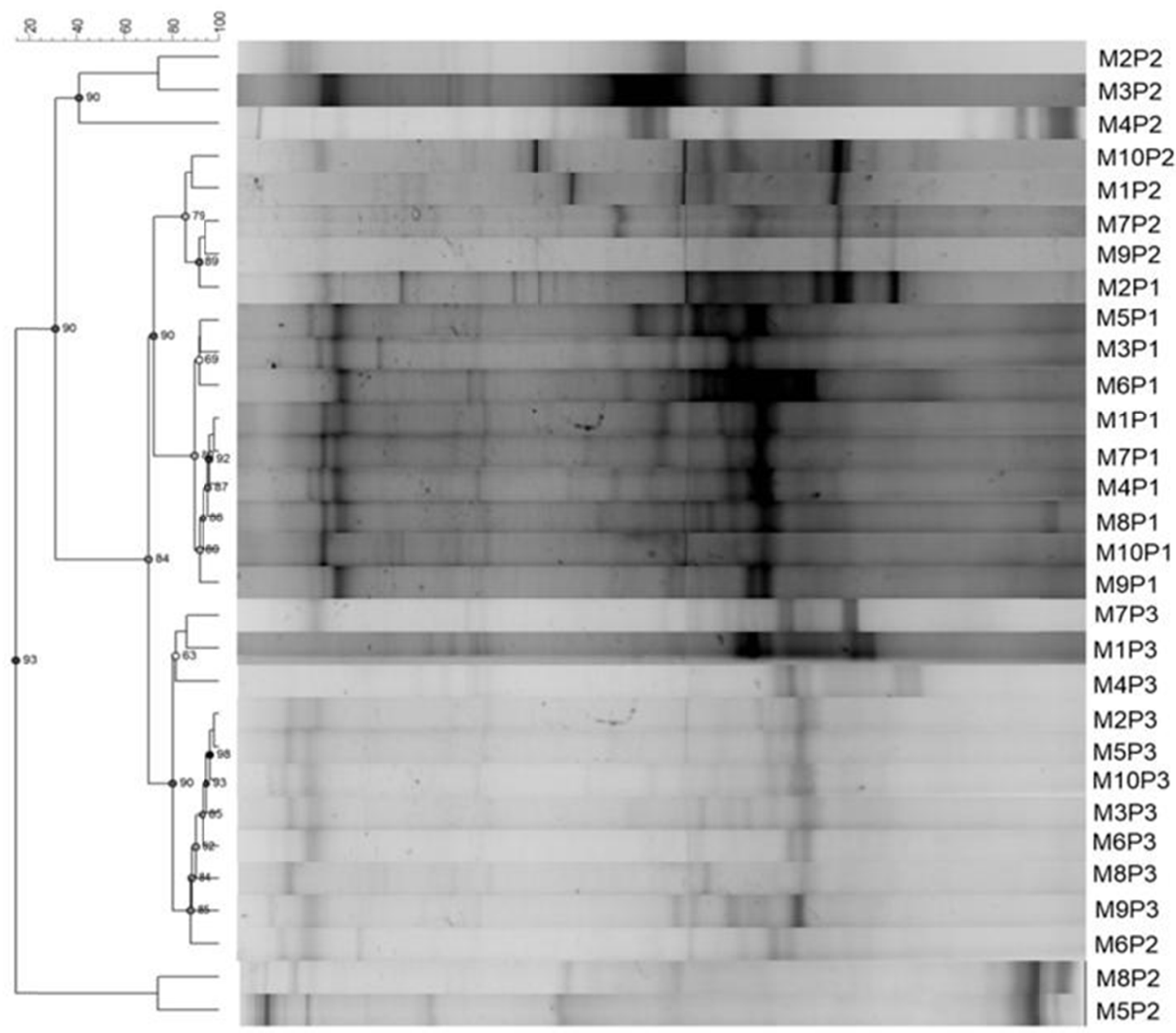

Figure 8. UPGMA dendogram and DGGE profile of $18 S$ rDNA gene from Cerrado soil after the use of biofertigation (M1 at M10) with wastewater/manure from cattle slaughterhouse. P1: 0-10 cm, P2: 10-20 cm, P3: 20-30 $\mathrm{cm}$ of soil depth (See the Table 1)

In the UPGMA dendogram and in the DGGE profile were observed AMF clusters in function of soil depth (Figure 8). In the depths of 0-10 (P1) and 20-30 cm (P3) a bands cluster inside the gel was observed. While in the other depth, the group was observed in the upper and lower parts of the gel. These clusters show that the addition of the wastewater/manure had little influence on the AMF community. In addition, in 20-30 cm soil depth was observed low number and intensity of bands. Thus, the diversity and abundance of AMF at this depth remained low even after application of the wastewater/manure in the soil that may be due to the limitation of nutrients and oxygen. In shallower (newer) and deeper (older) Amazonian soil strata also has difference in AMF and bacteria populations (Pagano et al., 2016). According to these authors, the chemical attributes were related with the AMF species in five soil depths. These results corroborate that the diversity of AMF is more influenced by soil depth than fertilization management.

Similar to that observed in the NFB profiles, the AMF community analysis by DGGE showed to be a good parameter to investigate the potential for use of wastewater/manure from cattle slaughterhouse in agricultural crop irrigation, especially forage crops (Figures 4, 5, 7 and 8). However, the NFB was more sensitive than AMF, which is mainly due to two factors. The sensitivity of NFN to different managements can also be observed in studies with more than 20 years duration with or without nitrogen fertilization (Tang et al., 2017; Wang et al., 2017).

Bacteria and fungi are, respectively, unicellular and multicellular microorganisms. Thus, in the samples there is a greatest possibility of having a greatest diversity of bacteria than of fungi. Pagano et al. (2016) showed higher amount of bacteria cell than of fungi cell in Amazonian soil. 
Second factor and perhaps most important is the time of germination and or growth. NFB may be free-living or symbiotic. Thus, they can grow and multiply on the soil without necessarily being associated with another living organism. However, the AFM depend on being associated with the plants roots for growth and reproduction (Moreira \& Siqueira, 2006). Moreover, the sexual reproduction of AFM depends on spore germination (Madigan et al., 2010; Moreira \& Siqueira, 2006). In this context, to verify the alterations on the AMF community after the management of depends on a longer time than the NFB. However, the seven months of soil management could have been adequate to investigate microbial changes in soil. Several authors have shown that the soil microbial community undergoes rapid changes in relation to environmental conditions (Faleiro \& Andrade, 2011; Barros et al., 2010; Moreira \& Siqueira, 2006). Furthermore, the AMF communities were most similar among samples from a similar geographical location (Figures 5 and 8). The AMF has also divergence in management types within a given location (Schneider et al., 2015).

Therefore, the DGGE profile of NFB and AMF before and after biofertigation was a good parameter to diagnose the efficacy of wastewater/manure as an alternative biotechnological irrigation, which will provide a reduction in the water demand of the water bodies.

\section{Conclusions}

In this study, we had the following conclusions:

(1) Biofertigation with wastewater form the green line of a cattle slaughterhouse contributes for development of forage crops in Cerrado soil.

(2) The nutrients of wastewater from the green line do not have a significant infiltration in the soil.

(3) Biofertigation with wastewater or manure from the green line has a positive influence on the increase in the number of viable microbial cells and the amount and intensity of NFB and AMF bands on the DGGE.

(4) The increase of the microbial biomass in the soil causes an increase, directly proportional, in the biomass productivity of Brachiaria brizantha $\mathrm{cv}$. Marandu.

(5) The evaluation of the NFB and AMF communities by DGGE showed to be a good parameter to study the changes caused by biofertigation managements in the Cerrado soil.

(6) The wastewater may be a viable alternative to reduces or eliminates the use of commercial fertilizers for Marandu grass production in the Cerrado soil.

\section{Acknowledgements}

The authors are grateful for the financial, scientific and structural support of CAPES, CNPQ, IFTO, BIONORTE, CEULP/ULBRA, UFV and UFT.

\section{References}

Alderson, M. P., dos Santos, A. B., \& Mota Filho, C. R. (2015). Reliability analysis of low-cost, full-scale domestic wastewater treatment plants for reuse in aquaculture and agriculture. Ecological Engineering, 82, 6-14. https://doi.org/10.1016/j.ecoleng.2015.04.081

APHA (American Public Health Association). (2005). Standard Methods for the Examination of Water and Wastewater (21st ed.). American Water Works Association (AWWA) \& Water Environment Federation (WEF).

Azevedo, M. R. Q. A., Konig, A., Beltrão, N. E. M., Azevedo, C. A. V., Tavares, T. L., \& Soares, F. A. L. (2007). Efeito da irrigação com água residuária tratada sobre a produção de milho forrageiro. Revista Brasileira de Ciências Agrárias, 2(1), 63-68. https://doi.org/10.5039/agraria.v2ila392

Barbero, R. P., Barbosa, M. A. A. F., Castro, L. M., Ribeiro, E. L.A., Mizubuti, I. Y., Massaro Júnior, F. L., \& Silva, L. D. F. (2012). Ingestive behavior of steers grazing under different heights of Tanzânia grass. Semina: Ciências Agrárias, 33(2), 3287-3294. https://doi.org/10.5433/1679-0359.2012v33Supl2p3287

Barros, Y. J., Melo, V. F., Dionísio, J. A., Oliveira, E. B., Caron, L., Kummer, L., Azevedo, J. C. R., \& Souza, L. C. P. (2010). Soil quality indicators in lead mining and metalurgy area: I-Microrganisms. Revista Brasileira de Ciência do Solo, 34, 1397-1411. https://doi.org/10.1590/S0100-06832010000400037

Bloom, A. J. (2015). The increasing importance of distinguishing among plant nitrogen sources. Current Opinion in Plant Biology, 25, 10-16. https://doi.org/10.1016/j.pbi.2015.03.002

Brower, R. (1962). Nutritive influences on the distribution of dry matter in the plant. Netherlands Journal of Agricultural Science, 10(5), 342-399. http://edepot.wur.n1/382088 
Christofidis, D. (2006). Oportunidades de irrigação no Cerrado: recursos hídricos dos cerrados e seu potencial de utilização na irrigação. Revista Item: Irrigação e Tecnologia Moderna, 69/70, 87-97. Retrieved from http://cienciaecultura.bvs.br/scieloOrg/php/reflinks.php?refpid=S0009-6725201100030001100005\&lng=pt \&pid $=$ S0009-67252011000300011

Cornejo, P., Azcon-Aguilar, C., Barea, J. M., \& Ferrol, N. (2004). Temporal Temperature Gradient Gel Electrophoresis (TTGE) as a tool for the characterization of arbuscular mycorrhizal fungi. FEMS Microbiology Letters, 241, 265-270. https://doi.org/10.1016/j.femsle.2004.10.030

Costa, N. L., Moraes, A., Carvalho, P. C. F., Monteiro, A. L. G., Motta, A. C. V., \& Oliveira, R. A. (2016). Growth dynamic and forage yield of Trachypogon plumosus under levels of soil fertility correction and regrowth ages. Ciência Animal Brasileira, 17(2), 175-184. https://doi.org/10.1590/1089-6891v17i218715

da Silva, J. M. C., Prasad, S., \& Diniz-Filho, J. A. F. (2017). The impact of deforestation, urbanization, public investments, and agriculture on human welfare in the Brazilian Amazonia. Land Use Policy, 65, 135-142. https://doi.org/10.1016/j.landusepol.2017.04.003

Direito, I. C. N., \& Teixeira, K. R. S. (2002). Simulation and behaviour of partially amplified nifh gene products migration rate during DGGE. Revista Universidade Rural, 22, 123-129.

Dunbar, J., Barns, S. M., Ticknor, L. O., \& Kuske, C. R. (2002). Empirical and Theoretical Bacterial Diversity in Four Arizona Soils. Applied and Environmental Microbiology, 68, 3035-3045. https://doi.org/10.1128/ AEM.68.6.3035-3045.2002

Embrapa (Empresa Brasileira de Pesquisa Agropecuária). (1984). Destaque dos principais resultados pesquisa de 1983 (p. 88). Brasília, Embrapa-ATA.

Embrapa (Empresa Brasileira de Pesquisa Agropecuária). (2006). Sistema brasileiro de classificação de solos (2nd ed., p. 306). Rio de Janeiro: EMBRAPA-SPI.

Faleiro, F. G., \& De Andrade, S. R. M. (2011). Biotecnologia: Estado da arte e aplicações na agropecuária (p. 730). Embrapa Cerrados.

Folli-Pereira, M. S., Meira-Haddad, L. A. S., Bazzolli, D. M. S., \& Kasuya, M. C. M. (2012). Micorriza arbuscular e a tolerância das plantas ao estresse. Revista Brasileira de Ciência do Solo, 36, 1663-1679. https://doi.org/10.1590/S0100-06832012000600001

Gloaguen, T. V., Gonçalves, R. A. B., Forti, M. C., Lucas Y., \& Montes C. R. (2010). Irrigation with domestic wastewater: A multivariate analysis of main soil changes. Revista Brasileira de Ciência do Solo, 34, 1427-1434. https://doi.org/10.1590/S0100-06832010000400038

Guo, W., Zhao, R., Zhao, W., Fu, R., Guo, J., Bi, N., \& Zhang, J. (2013). Effects of arbuscular mycorrhizal fungi on maize (Zea mays L.) and sorghum (Sorghum bicolor L. Moench) grown in rare earth elements of mine tailings. Applied Soil Ecology, 72(1), 85-92. https://doi.org/10.1016/j.apsoil.2013.06.001

Helgason, T., Fitter, A. H., \&Young, J. P. W. (1998). Ploughing up the wood-wide web? Nature, 394(6692), 431. https://doi.org/10.1038/28764

Hespanhol, I. (2002). Potencial de reuso de água no Brasil: Agricultura, indústria, municípios, recarga de aquíferos. Revista Brasileira de Recursos Hídricos, 7(4), 75-95. https://doi.org/10.21168/rbrh.v7n4.p75-95

Ibekwe, A. M., Gonzalez-Rubio, A., \& Suarez, D. L. (2018). Impact of treated wastewater for irrigation on soil microbial communities. Science of the Total Environment, 622-623, 1603-1610. https://doi.org/10.1016/ j.scitotenv.2017.10.039

IBGE (Instituto Brasileiro de Geografia e Estatística). (2015). Produção da pecuária municipal (Vol. 43, pp. 1-49). Rio de Janeiro, Brazil.

Koura, A., Fethi, F., Lahlou, A., \&OuazzaniI, N. (2013). Reuse of urban wastewater by combined stabilization pond system en Benslimane (Marocco). Urban Water, 4, 373-378. https://doi.org/10.1016/S1462-0758(01) 00067-X

Kowalchuk, G. A., De Souza, F. A., \&Van Veen, J. A. (2001). Community Analysis of Arbuscular Mycorrhizal Fungi Associated with Ammophila arenaria in Dutch Coastal Sand Dunes. Molecular. Ecology, 11, 571-581. https://doi.org/10.1046/j.0962-1083.2001.01457.x 
Liang, Z., Drijber, R. A., Lee, D. J., Dwiekat, I. M., Harris, S. D., \& Wedin, D. A. (2008). A DGGE-cloning method to characterize arbuscular mycorrhizal community structure in soil. Soil Biology and Biochemistry, 40, 956-966. https://doi.org/10.1016/j.soilbio.2007.11.016

Lima, J. E. F. W., \& Silva, E. M. (2007b). Estimativa da contribuição hídrica superficial do Cerrado para as grandes regiões hidrográficas brasileiras [CD-ROM]. Simpósio Brasileiro de Recursos Hídricos, 17, São Paulo.

Lima, J. E. F. W., Sano, E. E., Silva, E. M., \&Lopes, T. S. S. (2007a). Levantamento da área irrigada por pivô-central no Cerrado por meio da análise de imagens de satélite: Uma contribuição para a gestão dos recursos hídricos [CD-ROM]. Simpósio Brasileiro de Recursos Hídricos, 17, São Paulo.

Madigan, M. T., Martinko, J. M., Dunlap, P. V., \& Clark, D. P. (2010). Microbiologia de Brock (12th ed., p. 1091). Porto Alegre: Artmed.

Martin, J. P. (1950). Use of acids rose-bengall and streptomicin in theplate method for estimating soil fungi. Soil Science, 134, 215-232. https://doi.org/10.1097/00010694-195003000-00006

Moreira, F. M. S., \& Siqueira, J. O. (2006). Microbiologia e bioquímica do solo. Lavras: UFLA,

Neeraj, K. S. (2011). Organic amendments to soil inoculated arbuscular mycorrhizal fungi and Pseudomonas fluorescens treatments reduce the development of root-rot disease and enhance the yield of Phaseolus vulgaris L. European Journal of Soil Biology, 47, 288-295. https://doi.org/10.1016/j.ejsobi.2011.07.002

Pacheco, J. W. (2006). Guia técnico ambiental de abates (bovino e suíno) (p. 98). São Paulo: Cetesb. Retrieved from http://www.fiesp.com.br/arquivo-download/?id=4260

Pagano, M. C., Ribeiro-Soares, J., Cançado, L. G., Falcão, N. P. S., Gonçalves, V. N., Rosa, L. H., ... Jorio, A. (2016). Depth dependence of black carbon structure, elemental and microbiological composition in anthropic Amazonian dark soil. Soil \& Tillage Research, 155, 298-307. https://doi.org/10.1016/j.still. 2015.09.001

Pimentel-Gomes, F. (2000). Curso de estatística experimental (p. 14). Piracicaba: Esalq-USP.

Raij, B., Andrade, J. C., Cantarella, H., \& Quaggio, J. A. (2001). Análise química da fertilidade dos solos tropicais (p. 285). Campinas: IAC. Retrieved from http://www.iac.sp.gov.br/produtoseservicos/analisedo solo/livro.php

Rocha, R. E. M., Pimentel, M. S., \& Zago, V. C. P. (2003). Evaluation of biosolid fed by municipal waste-water sludge as a fertilizer in kale. Pesquisas Agropecuárias Brasileiras, 38, 1435-1441. https://doi.org/10.1590/ S0100-204X2003001200010

Rodrigues, A. C., Silveira, J. A. G, Bonifacio, A., \& Figueiredo, M. V. B (2013). Metabolism of nitrogen and carbon: Optimization of biological nitrogen fixation and cowpea development. Soil Biology and Biochemistry, 67, 226-234. https://doi.org/10.1016/j.soilbio.2013.09.001

Rodrigues, O. D. (2007). Influência da comunidade microbiana do solo no estabelecimento de sauveiros iniciais de Atta sexdens rubropilosa Forel, 1908 (Hymenoptera: Formicidae) (p. 64, Dissertação, Universidade de São Paulo, Escola Superior de Agricultura “Luiz de Queiroz"). Retrieved from http:/www.teses.usp.br/teses/disponiveis/11/11146/tde-21022008-170227/en.php

Ronquim, C. C. (2010). Soil fertility concepts and proper management for tropical regions. Embrapa, Campinas/SP. Retrieved from https:/www.embrapa.br/busca-de-publicacoes/-/publicacao/882598/conceitos -de-fertilidade-do-solo-e-manejo-adequado-para-as-regioes-tropicais

Rufini, M., Ferreira, P. A. A., Soares, B. L., Oliveira, D. P., Andrade, M. J. B., \& Moreira, F. M. S. (2011). Symbiosis of nitrogen fixing bacteria with common bean in different $\mathrm{pH}$ values. Pesquisa Agropecuária Brasileira, 46(1), 81-88. https://doi.org/10.1590/S0100-204X2011000100011

Sabino, D. C. C. (2007). Interação planta-bactéria diazotrófica na cultura de arroz (Tese de Doutorado. Universidade Federal Rural do Rio de Janeiro, Seropédica, RJ). Retrieved from http://livros01.livrosgratis. com.br/cp099812.pdf

Schneider, K. D., Lynch, D. H., Dunfield, K., Khosla, K., Jansa, J., \& Voroney, R. P. (2015). Farm system management affects community structure of arbuscular mycorrhizal fungi. Applied Soil Ecology, 96, 192-200. https://doi.org/10.1016/j.apsoil.2015.07.015 
SEPLAN. (2013). Geographical Atlas of Tocantins. Governo do Estado do Tocantins. Retrieved from http://seplan.to.gov.br/zoneamento/atlas-do-tocantins

Silva, J. G. D. (2017). Biotechnology of use of domestic wastewater in Cerrado soil to cultivation of Brachiaria brizantha cv Marandu (p. 100). Biotecnologia e Biodiversidade da Rede Bionorte, Universidade Federal do Tocantins. Retrieved from https://repositorio.uft.edu.br/bitstream/11612/356/1/Jos\%C3\%A9\%20Geraldo\% 20Devalux\%20Silva\%20-\%20Tese.pdf

Silva, J. G. D., Carvalho, J. J. E., da Luz, J. M. R., \& da Silva, J. E. C. (2016). Fertigation with domestic wastewater: Uses and implications. African Journal of Biotechnology, 15, 20. https://doi.org/10.5897/ AJB2015.15115

Silva, R. F., Marco, R., Bertollo, G. M., Matsouka, M., \& Menegol, D. R. (2015). Influência do uso do solo na ocorrência e diversidade de AMFs em Latossolo no Sul do Brasil. Semina: Ciências Agrárias, 36(3), 1851-1862. https://doi.org/10.5433/1679-0359.2015v36n3Supl1p1851

Simon, L., Lalonde, M., \& Bruns, T. D. (1992). Specific amplification of $18 \mathrm{~S}$ fungal ribossomal genes from vesicular-arbuscular endomycorrhizal fungi colonizing roots. Applied and Environmental Microbiology, 58, 291-295. Retrieved from http://aem.asm.org/content/58/1/291

Smith, S. E., Facelli, E., Pope, S., \& Smith, F. A. (2010). Plant performance in stressful environments: Interpreting new and established knowledge of the roles of arbuscular mycorrhizas. Plant Soil, 326, 3-20. https://doi.org/10.1007/s11104-009-9981-5

Sousa Neto, O. N., Andrade Filho, J., Dias, N. S., Rebouças, J. R. L., Oliveira, F. R. A., \& Diniz, A. A. (2012). Fertigation of cotton with treated domestic sewage. Revista Brasileira de Engenharia Agrícola e Ambiental, 16, 200-208. https://doi.org/10.1590/S1415-43662012000200011

Sousa, E. S., Lima, F. W. B., Maciel, G. F., Sousa, J. P., \&Picanço, A. P. (2010). Water balance and climatic classification of Thornthwaite for the city of Palmas-TO. ResearchGate. Retrieved from https://www. researchgate.net/profile/Aurelio_Picanco/publication/267785050_Balanco_hidrico_e_classificacao_climatic a_de_Thornthwaite_para_a_cidade_de_Palmas-TO/links/55f742e-108aeba1d9ef601bf.pdf

Tang, Y., Zhang, M., Chen, A., Zhang, W., Wei, W., \& Sheng, R. (2017). Impact of fertilization regimes on diazotroph community compositions and $\mathrm{N}_{2}$-fixation activity in paddy soil. Agriculture, Ecosystems and Environment, 247, 1-8. https://doi.org/10.1016/j.agee.2017.06.009

Ueda, T., Suga, Y., Yahiro, N., \& Matsuguchi, T. (1995). Remarkable $\mathrm{N}_{2}$-fixing bacterial diversity detected in rice roots by molecular evolutionary analysis of nifH gene sequences. Journal of Bacteriology, 177, 1414-1417. https://doi.org/10.1128/jb.177.5.1414-1417.1995

Vale Júnior, J. F., Freitas, R. M. S., Uchôa, S. C. P., Souza, M. I. L., \& Cruz Souza, D. L. S. (2011). Chemical attribuites and microbial activity in soils converted to savanna for plantations of Acacia mangium Willd. in Roraima, Brazil. Revista Agroambiente, 5(1), 1-11. https://doi.org/10.18227/1982-8470ragro.v5i1.434

Van Elsas, J. D., \&Boersma, F. G. H. (2011). A review of molecular methods to study the microbiota of soil and the mycosphere. European Journal of Soil Biology, 47, 77-87. https://doi.org/10.1016/j.ejsobi.2010.11.010

Vance, C. P. (1998). Legume symbiotic nitrogen fixation: Agronomic aspects. In. Spaink, H.P. The Rhizobiaceae (pp. 509-530). Dordrecht: Kluwer Academic Publishers. https://doi.org/10.1007/978-94-011-5060-6_26

Verma, N., Tarafdar, J. C., Srivastava, K. K., \& Panwar, J. (2008). Arbuscular Mycorrhizal (AM) Diversity in Prosopis cinerária (L.) Druce under Agroecosystems. Agriculture Science China, 7(6), 754-761. https://doi.org/10.1016/S1671-2927(08)60111-X

Von Sperling, M. (2005). Principle of biological treatment of wastewater (3rd ed., p. 452). Universidade Federal de Minas Gerais, Belo Horizonte.

Wang, C., Zheng, M., Song, W., Wen, S., Wang, B., Zhu, C., \& Shen, R. (2017). Impact of 25 years of inorganic fertilization on diazotrophic abundance and community structure in an acidic soil in southern China. Soil Biology \& Biochemistry, 113, 240-249. https://doi.org/10.1016/j.soilbio.2017.06.019

Wartiainen, I., Erikssont, T., Zheng, W., \& Rasmusse, U. (2008). Variation in the active diazotrophic community in rice Paddy nif H PCR-DGGE analysis of rhizosphere and bulk soil. Applied Soil Ecology, 39, 65-75. https://doi.org/10.1016/j.apsoil.2007.11.008 
Zehr, J. P., Jenkins, B. D., Short, S. M., \& Steward, G. F. (2003). Nitrogenase gene diversity and microbial community structure: A cross-system comparison. Environmental Microbiology, 5, 539-554. https://doi.org/ 10.1046/j.1462-2920.2003.00451.x

\section{Copyrights}

Copyright for this article is retained by the author(s), with first publication rights granted to the journal.

This is an open-access article distributed under the terms and conditions of the Creative Commons Attribution license (http://creativecommons.org/licenses/by/4.0/). 